Cuadernos Filosóficos. Segunda Época, XII, 2015

Modernidad y decadentismo en Charles Baudelaire

Sebastián ASSAF

\title{
MODERNIDAD Y DECADENTISMO EN CHARLES BAUDELAIRE
}

\author{
Modernity and decadentism in Charles Baudelaire
}

\section{Sebastián Assaf}

\author{
Universidad Nacional de Rosario (Rosario, Santa Fe, Argentina)
}

sebas_assaf@hotmail.com

\begin{abstract}
Resumen: Este texto desea captar la paradójica consustancialidad de modernidad y decadencia que configura la singularidad lírica de Charles Baudelaire. En una primera parte, intentaremos demostrar que lo moderno en Baudelaire es una manera de conjugar el tiempo y la belleza que resulta heterogéneo respecto a la forma de conformación que de ellos hace tanto la estética clásica como la romántica. En una segunda parte, una vez visualizado el vínculo entre lo moderno y la decadencia, buscaremos circunscribir el modo en que la poética de Baudelaire se singulariza a partir de una crítica respecto de las posiciones heredadas. Para este fin, desarrollaremos tres tópicos (antinaturaleza, des-subjetivación y alegoría) a partir de los cuales se nos haba visible aquello que, al devenir fundamental para Baudelaire, lo distancia al mismo tiempo y de forma definitiva, respecto de sus antecesores.
\end{abstract}

Palabras clave: Modernidad, Decadentismo, Alegoría, Baudelaire

\begin{abstract}
This text aims to capture the paradoxical consubstantiality of modernity and decadence that shapes Charles Baudelaire's lyrical singularity. In the first part, we will try to demonstrate that the modern in Baudelaire is a way of combining time and beauty, which is something different than what classical and romantic aesthetics does. In the second part, once we have visualized the connection between what is modern and decadence, we will try to circumscribe the way in which Baudelaire's poetics adopts a singular perspective in the way it criticizes the inherited traditions. In order to achieve this goal, we will develop three topics (anti-nature, desubjectification and allegory) from which we will be able to see what distances Baudelaire from his predecessors.
\end{abstract}

Keywords: Modernity, Decadence, Allegory, Baudelaire

Publicado bajo licencia Creative Commons Atribución-

Sin Derivar 4.0 Internacional (CC BY-ND 4.0)

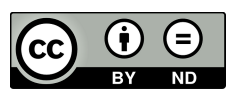




\section{Introducción}

"Quien encuentre a Homero solamente interesante, lo profana" (Schlegel 1995a, p. 138)

El ingenuo visitante del Louvre que evoca mordazmente Baudelaire al comienzo de El pintor de la vida moderna es el agente involuntario de una doble aberración. A la vez que profana la eterna belleza del arte clásico con la pueril pompa satisfecha que motiva lo meramente interesante, desatiende esos cuadros de "segundo orden" que, sin embargo, mantienen respecto a él una marcada afinidad estética y una intrínseca proximidad temporal. Dichos cuadros, en cuanto declinar de lo solamente interesante, característico u obtusamente parcial, se revelan, más allá de su embrionaria vacilación, paradójicamente esenciales. Lejos de toda culpa, nuestro crédulo visitante no hace más que consustanciarse con su tiempo. En su tozuda inobservancia devela en acto la inconsistente fluidez de su goce estético. Desvarío espiritual con el que se consagra a lo exclusivamente circunstancial. Pues el superfluo ajetreo de nuestro ignoto personaje concentra, en su ánimo decadente, la infinitud de su verdad. La infinitud, es decir, todo aquello que la trivial caducidad de una época promueve como su auténtica forma de gravitar.

Lo que ignora nuestro visitante respecto de su experiencia estética son los condicionantes temporales e históricos de sus apreciaciones. Lo sepa o no, lo suyo muy difícilmente pueda escapar a la profanación. La luz crepuscular de un tiempo indigente desacredita cualquier inclinación por la quietud de lo armónicamente impasible. Toda ínfula de severa unidad suscita inmediatamente lo risible. Condenado al sacrilegio, incita su brumosa curiosidad hacia lo interesante. Pero tal vez, llegado el caso, hasta lo interesante mismo finalmente falte. Entonces percibe un gélido vacío que se destaca, luminiscencias que sobreviven un instante suspendido a su definitiva desaparición como restos inquietantes bajo la cadencia sincopada de una urbana levedad. Estas luminiscencias representan las posesiones que el flâneur orgullosamente colecciona. Obsesiones de presencias instantáneas, develan la remanencia de una espectralidad difusa arrancada furtivamente a la erosionada luz de algún boulevard. Esta incipiente práctica de lo fugaz que irrumpe definitivamente a la conciencia moderna con Baudelaire, es aquello que buscamos. La experiencia estética de la vida moderna con su precario fundamento y su excéntrica 
autenticidad, anhelo de goce desesperado ante la imagen de una belleza que inevitablemente se disipa.

Lo moderno en Baudelaire se inscribe, por lo tanto, como un modo singular de configuración de la belleza en relación al tiempo. Singularidad que hace de la fugacidad de lo actual la materia en la que lo bello resplandece por un instante suspendido a su definitiva desaparición. En primer lugar, nuestro deseo será demostrar que la particularidad de dicha relación debe ser leída sobre el fondo de dos disposiciones heterogéneas a las que finalmente excluye. Por un lado, respecto de la imitación que en el ámbito del Clasicismo sostiene la relación entre la belleza y el tiempo bajo el predominio de una poética del duelo. Por el otro, ante lo interesante que somete la ligadura entre la belleza y el tiempo a la temporalidad inmanente de la subjetividad. Bajo esta tesitura, la naciente modernidad estética en Baudelaire aparece como un movimiento que tiende a la convergencia, por lo demás asombrosamente paradójica, con la vital decrepitud de una época que siente hundirse definitivamente en el ocaso.

En segundo lugar, una vez establecida la ligadura entre Modernidad y Decadentismo en Baudelaire, intentaremos demostrar que su poética sólo puede comprenderse sobre la base de una ruptura con los posicionamientos heredados, en particular con aquellos que provienen de forma manifiesta de la estética romántica. Con este fin, desarrollaremos tres tópicos que a la vez que se muestran fundamentales para comprender a Baudelaire, se presentan como puntos de inflexión respecto de la tradición del Romanticismo. La antinaturaleza, la des-subjetivación y la alegoría. Como afirma T. S. Eliot en su ensayo sobre Baudelaire, éste no sólo se ha adelantado "al punto de vista de su época" siendo, en este sentido, un puente con escrituras futuras, sino que simultánea y principalmente, fue "un hombre de su época", un epítome de su tiempo, es decir, alguien que capturó su esencia trivial porque participó tanto de sus "limitados méritos", como de sus “defectos y modas" (Eliot 2015, p. 245). Por último, sólo nos queda la espera y el anhelo de haber logrado dar cuenta de nuestros propósitos.

\section{Belleza y temporalidad}

\section{1. La Imitación}


Si en tiempos de Baudelaire la profanación aparece como un destino, es porque la imitación se descubre a los ojos de su actualidad, como una vaga ensoñación o superfluidad absolutamente irrealizable. En este sentido, Baudelaire se nos presenta como el arquetipo del artista moderno, -cuyo perfil maldito se encuentra instalado con anterioridad incluso al tópico derivado del texto de Verlaine, perfil que, por lo demás, será clonado hasta el hartazgo por las generaciones venideras de artistas de vanguardia- ya que con él se decide finalmente la tensión irresuelta de una añeja querella. En su insoluble mezcla tan personal como enigmática de empecinamiento fútil y rigor crítico, Habermas advierte la significativa determinación que posee la crítica estética para el problema fundamental de la autojustificación de la modernidad. La escisión a partir de la cual se puede diferenciar una época como excrecencia retirada de otra surge a principios del siglo XVIII con la querelle des anciens et des modernes. "Los «modernos» ponen en cuestión el sentido de la imitación de los modelos antiguos con argumentos histórico-críticos, elaboran frente a las normas de una belleza en apariencia sustraída al tiempo, de una belleza absoluta, los criterios de una belleza sujeta al tiempo o relativa y articulan con ello la autocomprensión de la ilustración francesa como comienzo de una nueva época" (Habermas 2012, p. 18).

El "comienzo de una nueva época" significa que esa "nova aetas" se ve sustraída del horizonte teológico cristiano como "edad todavía por venir" y, en tanto tal, prometida y definitiva, para transmutarse en un ahora naciente, es decir, actual y profano. La concepción temporal supeditada a la dimensión secular queda circunscripta como experiencia de lo abierto, lo siempre ya orientado, el futuro ya comenzado y ya actuante en cada ahora presente (Ibid., p. 15). Pero "nueva época" también señala la apertura de un espacio crítico en el que se pone en cuestión el sentido de la imitación, hecho que implica que previamente se haya sancionado que la imitación debe tener algún sentido. Ahora bien, la belleza y el tiempo mantienen una solidaria consustancialidad con la que se articula, en íntima inherencia, el sentido de la imitación. O lo que es lo mismo, toda imitación es subsidiaria de un vínculo particular entre un modo de entender lo bello y un modo de concebir la temporalidad, enlazados a la ley implícita de una presupuesta filosofía de la historia. De ahí que no deba sorprendernos que en las antípodas de la asunción del destino como profanación, Winckelmann se arroje al solo destino de la imitación. "Nuestro único camino para ser grandes, más aún, para ser, si es posible, inimitables, es la imitación de los 
antiguos, y lo que alguien dijo de Homero, que sólo aprende a admirarlo quien ha aprendido a conocerlo, también vale para las obras de arte de los antiguos, en particular de los griegos" (Winckelmann 2008, p. 78).

Si la conjunción de Spleen e Ideal comunica en Baudelaire la experiencia estética por la vía del advenimiento de lo alegórico como corte sobre el continuo realizado de agotamiento y agonía, en Winckelmann, por el contrario, toda experiencia se transfiere en la borradura de la realidad del objeto y por la sola vía del Ideal. El sentido de la imitación es entonces la imitación del Ideal. En ese retorno a los antiguos que transita por la senda del Ideal se fundamenta, sin embargo, una novedad. Como enuncia Didi-Huberman, como resto de la "restauración" neoclásica, Winckelmann culmina inventando la historia del arte como intento de superación, tanto de "la simple cronología" de tinte pliniano o vasariano, como de la multiplicidad implícita en la arbitrariedad del juicio de gusto. Por este acto se decide un nuevo comienzo que transforma el enjambre de disjecta membra, los "amasijos de restos" del arte antiguo en una bella corporeidad. "Winckelmann funda una historia del arte menos por lo que descubre que por lo que construye" (Didi-Huberman 2013, p. 12).

El retorno al pasado inicia en el tiempo. El inicio crea aquello que se descubre. Esto es así porque en el ahora del instante de la creación confluyen inextricablemente el nacimiento con la muerte. Es el cadáver (cadere), el objeto caído, aquello que abre el ahuecamiento desde donde toda novedad puede advenir o acontecer a la presencia. De ahí la aparente paradoja de que la naciente disciplina de la nueva época se instituya subordinada respecto de lo muerto. "Los libros a menudo están dedicados a los muertos", señala Didi-Huberman (2013) en referencia a Winckelmann (p. 13). Para un historiador cuya mirada se conforma bajo el esquema de grandeza y decadencia (grandeza antigua y decadencia moderna), la naciente historia moderna del arte no puede sino suscribirse a la temporalidad del duelo. Es la nostalgia, a la vez que la simultánea sutura por lo perdido, el movimiento que habilita toda instancia de imitación. Puesto que la imitación reproduce el esquema de una repetición diferencial y, por lo tanto, transfiere por la vía del Ideal en el mismo instante en que constata la desaparición real de su objeto. "El arte antiguo -el arte 
absolutamente bello- brilla, pues, en su primer historiador moderno, por una «ausencia categórica»" (Ibid., p. 14). ${ }^{1}$

Ahora bien, la desmesura de esta ausencia no puede leerse de otro modo que como pesimismo. Pues la grandeza, que en parte habilita, se torna simultáneamente inalcanzable, y por eso mismo, sobreviene frustrante. Así deviene, entonces, imperiosamente normativa. La absoluta belleza posee el rostro helado de un muerto que detrás de toda encarnadura actual, subvierte el tiempo histórico en "el tiempo vivido de nuestro duelo". Pero como correlato de esta operación, tras la pérdida de los objetos reales subsiste aún la esencia, es decir, el Ideal impasible de la eterna belleza. Esta Idea, esta eternidad depurada a lo muerto, se impone como el modelo que se debe alcanzar. "He aquí lo extraño: el ideal se aprehende, se reconoce, a través de una «contemplación real de los objetos», como escribe Winckelmann. Pero no a través de una contemplación de los objetos reales” (Ibid., p. 18). Condición de su transmisibilidad y, por lo tanto, de su imitación es la censura que el Ideal ejerce sobre toda aquella carnalidad que se mantenga supeditada a la caducidad del tiempo. Sólo lo bello permanece, sustraído a toda escoria temporal en la inmutable eternidad marmórea del Ideal.

El modelo salva las ruinas del arte antiguo de su irreversible desvanecimiento, pero simultáneamente las pierde en la blancura sin sombras del bello ideal. Fija la esencia para la voracidad de la mirada fascinada. Resguarda, de este modo, antiguos esplendores de su aciago destino de noche y olvido. Pero, ¿dónde persiste la esencia si los objetos reales ya se han desvanecido? ¿Cómo la totalidad de la esencia puede insistir en los residuos de bellezas estalladas? A la eterna belleza se accede por la "contemplación real de los objetos", es decir, mediante la sola realidad intelectual del espíritu. De ahí que toda belleza pueda ser salvada del vórtice abisal de su ruina material. Aquello que se debe imitar no está ni en la naturaleza, ni en lo que resista de naturaleza en la ruina. Pues la naturaleza es aún una laxa pluralidad difusa. Por el contrario, la belleza habita como en una corteza o epidermis

1 El quiasmo entre retorno e iniciación, novedad y repetición como constatación de una ausencia que por su espaciamiento habilita un nuevo comienzo deja leerse en Winckelmann en el intervalo que separa a los griegos de los modernos y a la naturaleza respecto del Ideal. El Ideal rige sobre los modernos que han asumido la ausencia categórica de su objeto. Winckelmann en su Historia del arte de la antigüedad, enuncia esta parábola. En referencia a los griegos dice que "una infinidad de cosas que para nosotros son ideales eran naturales para ellos" Winckelmann 1985, § 4, p. 106). Es la muerte de ese brotar natural entre los griegos aquello que deja un vacío en el que finalmente se transfiere el Ideal. 
imaginaria de las cosas, que es en ellas, aquello que éstas tienen de más elevado y espiritual. "Aunque la imitación de la naturaleza pudiera ofrecer todo al artista, por medio de ella, ciertamente, no podría alcanzar la corrección del contour, que sólo puede aprenderse de los griegos.” Lo que Winckelmann llama contour es la corrección procedente de una sublimación espiritual de las cosas y que, por ello, persiste al desvanecimiento inapelable del objeto. No es, por lo tanto, el mero contorno. El contour es la naturaleza en la medida en que ella es mediada por la concepción del sabio y alojada por la palabra del poeta. Es, por lo tanto, primacía simbólica. "En la figuras de los griegos, el contour más noble unifica o circunscribe todas las partes de la naturaleza más bella y de la belleza ideal, o es más bien el concepto más elevado de ambas" (Winckelmann 2008, p. 88). El contour es la unidad de lo heterogéneo, la veladura muerta que brilla imperecedera sobre las cosas, “principio que ennoblece y espiritualiza lo sensible común”.

Como lo muerto es incapaz ya de morir, se hace digno del Ideal decretando el llamado a la imitación. El acto de imitación al revivir la pérdida en el origen, repite la actualidad del origen reiniciándolo en el tiempo. "Ello sólo es posible porque el objeto de la imitación no es un objeto, sino el ideal mismo" (Ibid., p. 21). De ahí que, más allá del ardor restaurador del Clasicismo, la imitación consumada no puede sino resultar irremisiblemente fallida. Didi-Huberman habla de la alternancia depresiva y maníaca enlazada a la conjunción de vida y muerte que supura en todo instante que se pretende inicial. No se imita más que lo inimitable, lo imposible. Pero en la repetición de esta imposibilidad, sin embargo, algo sucede, algo pasa, "atraviesa el tiempo". Devenir inimitables como presagia Winckelmann, sólo es posible para aquellos que han experimentado la violencia infinita de esta imposibilidad, el paradójico movimiento de encontrar su deseo tras el resquemor dolorido por la pérdida irreparable del objeto amado.

\section{2. Lo interesante}

La desaparición del arte bello deja, sin embargo, su marca. Una herida categórica resiste como fantasma a su insondable borradura. En el mismo desvanecimiento, erige su imperativo en ley general y sofoca con su masa asfixiante, el acaecer de la novedad. En un texto de juventud, Friedrich Schlegel retorna a la problemática abierta medio siglo antes 
por Winckelmann. La poesía y el arte moderno se constituyen en la escisión respecto del arte antiguo. Lo nuevo ya no puede encontrar su satisfacción en el extravío de una mirada fascinada que anhela reponer el rostro de lo muerto sustrayéndolo a su destino de desaparición. En sintonía con su tiempo, la propuesta de Schlegel pretende la convergencia hacia un punto de síntesis de la antinomia entre lo antiguo y lo moderno. Pero tal ajuste entre opuestos conlleva, sin embargo, un vértigo paradojal. El retorno a Winckelmann será mediado por el movimiento excéntrico de las lecturas de Kant y Fichte. La retroversión de la mirada se entreteje en pretensiones de sistema y la imitación se ajusta al desencadenamiento dialéctico.

Lo curioso del texto no es justamente la solución a la que arriba, presunta síntesis emergiendo en la literatura de Goethe como insoluble conjunción de las esencias antigua y moderna, sino su fallido. La fractura que en él irrumpe entre ambas esencias y que decanta en un decrépito estado de "heteronomía estética" como atmósfera singular de la creación artística moderna. Existe una dimensión de la impostura solamente posible en el horizonte de esta época. El summum de la aberración es que la imitación de lo bello antiguo pueda acontecer como un subproducto de lo meramente interesante. "[La objetividad del arte es violada] por subjetividad cuando en una representación de validez general se mezcla en el juego la particularidad, se introduce furtiva y suavemente o se subleva de forma manifiesta" (Schlegel 1995a, p. 123). De manera que el aparecer de lo bello general y objetivo, encuentre su sostén en la evocación caprichosa y en la aberración artificial o afectada que produce el virtuosismo subjetivo y ocasional. En este sentido, lo interesante en el planteamiento de Schlegel es el modo en que se impone a la cavilación, en su irreversible insistencia, la interpelación por la esencia de lo moderno.

A la esencia de lo moderno pertenece el condicionante de que la Modernidad no haya logrado la generalidad solidaria de una cultura verdaderamente pública, de este modo, la auténtica belleza le permanece vedada. El desgarramiento es la ley entre los modernos, tragedia y comedia se ocluyen tras una lírica que canta el dolor de lo separado y la desesperación de lo aislado. "Así, lo bello no es el ideal de la poesía moderna, y es esencialmente distinto de lo interesante" (Ibid., p. 56). Lejos de toda pureza, el Ideal de la poesía moderna no puede sustraerse a la fealdad. En ella insisten, tanto una monstruosa ansiedad, como una excentricidad grotesca. La experiencia estética moderna se somete a 
"lo interesante, es decir, [a] la fuerza estética subjetiva" (Ibid., 53). En lo objetivo puede imperar aún el desinterés, pero bajo lo interesante todo deviene aprisionado por la tiranía subjetiva. Lo propio de esta tiranía es su anemia para la generación de entusiasmo. ${ }^{2}$ Lo interesante "entretiene" y como ya ha mostrado Montesquieu 3 , lo suyo es la variación infinita de un ansia afectada que se muestra como el remedio ante la espasmódica dicotomía entre el hartazgo complaciente y el sopor de la vaciedad. Así, lo interesante permanece impregnado de un "valor estético provisional" que se subyuga en continua obsolescencia. "Lo nuevo se vuelve viejo, lo peregrino, corriente, y los estímulos de lo atractivo se embotan" (Schlegel 1995a, p. 64). Por lo tanto, si la sorpresa es el estado placentero en el que el alma disfruta de su abrirse ingenuo hacia la novedad, esta búsqueda, no puede más que esclavizar el alma a lo interesante, ya que sólo lo interesante contiene la fuerza suficiente para autolimitarse, es decir, interrumpirse a sí mismo para devenir a su tiempo siempre algo aún más interesante.

Más allá de todo su impulso hacia el ideal, Schlegel percibe en su época el hiato insondable de lo abierto. Se hunde entonces en la ignominia, pues solamente en el vértigo de la caída se puede dar cuenta de las causas. El origen de lo interesante no se adecua a la temporalidad del duelo. Por el contrario, lo interesante se caracteriza por un "afán de realidad infinita" como contrapartida del hundimiento y de la degeneración de las formas perfectas del arte antiguo. Cuanto más impetuosamente la subjetividad reacciona ante la pérdida de la forma, tanto más la pierde, pues lejos de encontrarla como decantación de un proceso natural, cree obtenerla como mero acto desencantado de una decisión particular que, irónicamente y como correlato de su impulsividad, al realizar la bella apariencia, instantáneamente la extralimita, al consumarla bajo la égida obtusa de lo individual.

Schlegel no busca solamente demostrar la esencia del arte moderno, también aunque vale decir, más bien a su pesar- la repite en acto. De modo indirecto, el

2 En cambio Schlegel observa como elemento esencia de la poesía griega, la sólida amalgama entre entusiasmo y comunidad. "La poesía, el canto, el baile y la vida social: la alegría festiva eran el sonriente lazo de la comunidad que unía a los hombres con los dioses" (Ibid., p. 98).

3 "Montesquieu escribió en el Essai sur le Gout: «Todo nos cansa a la larga, y muy especialmente las más grandes alegrías; su final no satisface menos que su principio [...] Nuestra alma está harta de sentimiento, pero el no sentir nada significa caer en una vaciedad deprimente. El remedio está en una variación totalmente cambiante: así el alma siente sin cansarse [...] Esta propiedad de orientarse cada vez a objetos nuevos hace que el alma disfrute todas las alegrías que proceden de la sorpresa: esta sensación gusta al alma porque sucede algo y porque sucede rápido, pues el alma ve o siente algo que no espera, o de manera distinta a como esperaba [...]» (Münster 1995, pp. 158 - 159). 
descubrimiento deviene convincente precisamente por sustraerse o anticiparse al enunciado, y por develarse en el instante que es la temporalidad inherente a la enunciación. Los intervalos en los que la subjetividad se desencuentra con la forma sufren una celeridad creciente, subsidiaria de la repetida descarga de tensión producto del monto de ansiedad acumulada. No hay retorno que sea susceptible de salvar las ruinas del bello ideal. Tampoco belleza que resulte inmune a un tiempo desmesurado, desesperado, infinito y fugazmente perecedero. Lo interesante es el desquicio mismo del tiempo. Es el escándalo de la subjetividad violando a la objetividad en el mismo movimiento de volverse compasivo hacia ella. El sacrificio del viejo ideal se muestra entonces como el precio a pagar por la vida de lo interesante. Paroxismo de la individualidad aislada, lo interesante habita el espacio abierto por la negación de la objetividad antigua. De ahí que Schlegel, en cuanto que aún permanece prisionero del pecado de juventud que lo conmina a promover un optimismo dialéctico absolutamente falto de ironía cuya síntesis y superación ve cristalizar en Goethe 4 , conciba a lo interesante como "crisis pasajera del gusto" susceptible de superarse a sí mismo en la negación de su propia negatividad como autodestrucción de sí. "El dominio de lo interesante es sólo una crisis pasajera del gusto, pues al final tiene que destruirse a sí mismo" (Schlegel, 1995a, p. 81). Pero, ironía del tiempo, cuando lo provisorio y lo accidental tocan las fibras más íntimas de la realidad de las cosas, entonces, su precariedad sobreviene insólita supervivencia. No debe, por lo tanto, extrañarnos que sobre la previa disyuntiva de lo ideal y lo interesante, Schlegel haga emerger a la crítica moderna la inquietante meditación acerca de la fealdad como categoría estética.

Lo bello es tan poco dominante en la poesía moderna, que muchas de las obras más excelentes de ésta son evidentemente representaciones de lo feo; y al fin habrá que confesar, aunque a disgusto, que hay una representación de la confusión en su más alto grado, de la desesperación en toda su abundancia, que exige la misma -si no una más altafuerza creadora y sabiduría artística que la representación de la plenitud y la fuerza en perfecta armonía (Ibid., pp. 60 -61).

4 Tres años después, en 1797 Schlegel pone en práctica la reflexión autoirónica. Escribe en el fragmento [7] del Lyceum: "Mi ensayo sobre el estudio de la poesía griega es un himno amanerado en prosa a lo objetivo de la poesía. Lo peor de él me parece que es la absoluta falta de la indispensable ironía; y lo mejor, la confiada presuposición de que la poesía es infinitamente valiosa, como si esto fuera cosa probada." (Schlegel 1995b, pp. $47-48$ ). 
En ciertas circunstancias el ideal es incapaz de escapar a la profanación, pues la subjetividad lo desacredita con su mera existencia, es decir, lo expulsa en los hechos aun cuando desde el discurso manifiesto pretenda exaltarlo. Incluso todo "atisbo de belleza perfecta" se corresponde menos con el "goce tranquilo", emulación de la pretérita grandeza del clasicismo heleno, que con el virtuosismo violento de un ansia que se muestra insaciable por definición.

En las antípodas del "buen gusto" que Winckelmann presagiaba extenderse como corolario de la imitación, Schlegel percibe la carne corrupta del ideal deshacerse en una fealdad que se disemina al contagiarse como la peste. El eclipse del gusto fermenta con hedores de frustración y melancolía. Lo hace incluso en el contrapunto de un virtuosismo afectado que preserva para sí mismo todo tipo de extravagancias y caprichos en materia de gusto, y cuyo efecto inmediato es la sustracción de todo criterio. En analogía con el "tonel de las Danaides" del texto platónico, la supresión del límite declina en una insatisfacción imposible de colmar como correlato de un deleite sin finalidad obtenido por el derrumbe de su objeto. El resultado es una especie de sopor anárquico en materia estética. ${ }^{5}$ En esta abroquelada virulencia, cada obra se pretende despótica en su aislamiento, entonces, no se liga con otra más que a condición de una "violencia externa" que se ejerce arbitrariamente sobre la materialidad de los cuerpos. Así, su cohesión resulta inevitablemente impostada, la coagulación de un artificio, como artificial deviene el hipócrita enlace que confina al artista con su tiempo y con su semejante. "Pero los pocos rasgos comunes son muy fluctuantes, y en realidad cada artista existe para sí, un egoísta en medio de su época y de su pueblo" (Ibid., p. 74). La paradójica norma del caos moderno es indivisible del dolor y de la fealdad. Sólo el genio posee la fuerza interna suficiente para elevarse en la opacidad de este abismo. Interioridad inconmensurable, se instituye a sí mismo en la legitimidad de su infinito arrebato capaz de cristalizar en una forma original que excede, por eso mismo,

$5 \quad$ "Esta anarquía no se detiene en los límites externos, sino que se extiende a todo el terreno del gusto y del arte. La fuerza productora es incansable e inconstante; tanto la receptividad individual como la pública son siempre igual de insaciables e insatisfecha. La teoría misma parece desesperar por completo de [encontrar] un punto fijo en el cambio sin fin. El gusto público - pero ¿cómo sería posible un gusto público donde no hay costumbres públicas?-, la caricatura del gusto público, la moda, rinde homenaje cada momento a un ídolo distinto. Todo nuevo fenómeno brillante despierta la confiada creencia de que ahora se ha alcanzado la meta, la suma belleza, de que se ha encontrado la ley fundamental del gusto, la norma suprema de todo valor artístico. Mas el momento siguiente pone fin a la fiebre; entonces, llega la sobriedad, se destruye la imagen del ídolo mortal y se consagra en su lugar uno nuevo, ¡cuya divinidad a su vez no durará más que el capricho de sus adoradores!" (Ibid., p. 61). 
la austera rigurosidad de la norma bella. No sorprende que el paradigma del genio moderno, Schlegel lo encuentre -lo que se volverá un tópico para los románticos- en Shakespeare. ${ }^{6}$

Quien juzga a su poesía [de Shakespeare] como un arte bello, lo que hace es caer en contradicciones más profundas cuanta más sagacidad tenga y cuanto más conozca a ese poeta. Así como la naturaleza produce lo bello y lo feo mezclados con una riqueza exuberante por igual, así también Shakespeare. Ninguno de sus dramas es bello en conjunto; nunca la belleza determina la ordenación del todo. Al igual que en la naturaleza, incluso sus bellezas aisladas raras veces están libres de añadidos feos, y sólo son medios para otro fin; sirven al interés característico o filosófico (Idem.)

En la clausura del entusiasmo, lo interesante se goza en desesperación. En la privación de la alegría, lo moderno subsiste en el desgarrado dolor por lo separado. Hamlet representa la más lograda ejecución de este ánimo crepuscular. Plenitud de aislamiento, designa para Schlegel la consumación del "nihilismo poético". En una carta a su hermano August, Friedrich escribe:

Ayer noche leí el «Hamlet». (...) Pero no esperes nada extraordinario; lo que voy a decir quizá parezca muy vulgar y evidente, quizá un capricho rebuscado, quizá una exaltación extravagante. El objeto y el efecto de esta obra teatral es la desesperación heroica, es decir, una infinita perturbación de las supremas fuerzas. El motivo de su muerte interior está en la grandeza de su intelecto. Si fuera menos grande, sería un héroe. Para él no vale la pena ser un héroe, pues si quisiera, eso sería sólo un juego para él. Con su mirada abarca una incontable multitud de circunstancias; de ahí su indecisión. Pero si se pregunta así por la verdad, entonces enmudece la naturaleza; y para tales instintos, para un análisis tan riguroso, el mundo no es nada, porque nuestra frágil existencia no puede conseguir nada que satisfaga nuestras exigencias divinas. Lo más íntimo de la existencia de Hamlet es una horrible nada, desprecio del mundo y de sí mismo. (...) ¡Desgraciado quien lo entiende!

6 La sola descripción del arte de Shakespeare por parte de Schlegel orienta acerca de la lectura que posee sobre la esencia del artista moderno. "Su representación nunca es objetiva, sino manierista desde el principio hasta el fin; aunque yo soy el primero en confesar que su manera es la más grande, su individualidad la más interesante que conocemos hasta ahora. Ya se ha observado muchas veces que el sello original de su manera individual es inconfundible e inimitable. Quizá lo individual en general sólo pueda ser comprendido y representado individualmente. Por lo menos, el arte característico y la manera parecen ser compañeros inseparables, correlatos necesarios. Por manera entiendo en el arte una orientación individual del espíritu y una atmósfera individual de sensualidad expresada en representaciones que deben ser ideales" (Ibid., p. 80). 
Llegado el caso, esta obra podría ocasionar inopinadamente un suicidio (Münster 1995, pp. $16-17)$.

Con Hamlet irrumpe el imposible de la imitación que persiste aún como dividido anhelo en el texto de Schlegel. Ya no hay belleza pura por representar. No hay heroísmo cuya solemnidad no promueva la irresistible carcajada, pues en el ocaso de todo ideal del destino, el héroe se intuye contradictoriamente como producto absurdo en el arbitrio de lo interesante. Solamente subsiste la desesperación en la intensidad descomunal del aislamiento como espacio de la heroicidad irresoluta, el incesante morir como reflexión de la interioridad que se contempla a sí misma en su permanente vaciamiento.

Como en Hamlet, la agudeza del intelecto es el reverso del marchitamiento interior. Ganancia que es indisociable de la herida. De la putrefacción de todo amparo comunitario. Sin embargo, lo interesante encuentra su circuito pulsional a partir de esa muerte, de esa íntima e incesante vaciedad. Esa "horrible nada" en la que sólo sobreviven el desprecio por el mundo y por sí mismo. Así, la fealdad es el reflejo irreal que proyecta la hipertrofiada suficiencia de lo interesante. El efecto estético de su pecado mortal, que como el mal en Agustín es consecuencia inmediata de la vanidad, un soberbio rebajamiento que se precipita por el sendero del simulacro y del no ser.

El dolor animal en la representación de lo feo es sólo elemento y órgano de lo éticamente malo. Pero a lo absolutamente bueno no se le contrapone nada positivo, ningún mal absoluto, sino sólo una simple negación de la humanidad pura, de la totalidad, unidad, y pluralidad. Lo feo es pues en realidad una apariencia vacía en el elemento de un mal físico real, pero sin realidad moral. Sólo en la esfera de la animalidad hay un mal positivo: el dolor (Schlegel 1995a, pp. 120 - 121).

El dolor moral encuentra su espacialidad como suplemento irreal en la privación, es decir, aparece súbitamente como consecuencia del desvío reflexivo que lo interesante hace ante el precipicio de su nada. Por eso, se reproduce al infinito asentado sobre el fantasma de una huera subjetividad que esparce su negatividad como una sombra que diseca la faz desnuda de todas las cosas.

La poesía y el arte moderno no confluyen con el ideal de objetividad del clasicismo. Por el contrario, nacen de su disonancia, de su borradura, de la nada que impulsa a 
excederse por la vía blasfematoria de una profanación permanente. Lejos entonces de la sutura del duelo, su temporalidad es dispersión de una herida, una hemorragia que no cesa de no sanar. La primacía de lo interesante deviene el tiempo de lo patológico. Del interés por lo que se sufre, por la experiencia del corte que es sedimento del dolor. Por ese pathos que es el modo singular en que cada cual queda incondicionalmente prendado a su objeto. De ahí que aquello que Winckelmann -junto con todo clasicismo- censura, devenga la manera para todo arte Romántico o interesante. "Como si estas cosas estuviesen ligadas por alguna oscura patología común, Winckelmann expresará con igual radicalidad su rechazo del pathos, esa enfermedad del alma que deforma los cuerpos y, por lo tanto, arruina el ideal, que supone la serenidad de la grandeza y de la nobleza del alma" (Didi-Huberman 2013, p. 19) La sutileza de lo interesante se troca en ruina del ideal. Así, la fealdad es la consecuencia del caos interno que fermenta como viscosidad subjetiva y patológica. Pero, simultánea y escandalosamente, esta deformidad es el modo de lo moderno y por eso mismo, de una nueva sensibilidad y experiencia estética. "El arte moderno manifiesta su esencia en el Romanticismo; forma y contenido del arte romántico vienen determinados por la interioridad absoluta" (Habermas 2012, p. 29). El derrotero posterior de Schlegel, en cuanto que asume la configuración de la divina ironía, no hace más que zanjar definitivamente el rumbo adquirido por la creación artística moderna. A la esencia de lo moderno pertenece el ideal de lo inimitable o a lo sumo, el reverso de una imitación aberrante que es consecuencia misma de la mediación del pathos. En analogía con lo que atestigua el concepto de lo pintoresco, que emerge en el ámbito del paisaje romántico, en tanto que expresión de un nuevo punto de vista según el cual no es el Arte el que imita a la Naturaleza, sino que a la inversa, es ésta la que imita al Arte. Por lo tanto, tampoco es éste quien imita al Ideal sino que es el Ideal el que debe imitar o bien decantarse como una nota insólita o estúpida en el concreto y continuo despliegue de lo interesante.

Para finalizar, un par de puntuaciones que se proyectan ya sobre el plano de influencia estética de Baudelaire. En primer lugar, como consecuencia del inexorable predominio de lo interesante, el concepto de belleza sufre una inevitable ampliación de rango. En la belleza medusea se amalgama el dolor con el placer, por lo tanto, lo bello se contamina de lo horrendo y enfermizo como aliciente para el deseo. "El descubrimiento del horror, como fuente de deleite y de belleza, terminó por actuar sobre el mismo concepto de 
belleza: lo horrendo, en lugar de una categoría de lo bello, acabó por transformarse en uno de los elementos propios de la belleza. De lo bellamente horrendo se pasó, a través de una gradación insensible, a lo horrendamente bello" (Praz 1999, p. 69). La voluptuosidad se infecta de lo acre y provecto. En la proclividad al desorden, cristaliza la belleza turbia como efecto inmediato del desborde de la nueva sensibilidad. Esta turbiedad de lo bello llega incluso a la obtusa exasperación de lo grotesco. En la antinomia del ideal de objetividad de lo antiguo, el caos patógeno de lo moderno impulsa la forma hacia un continuo excederse cuyo límite conlleva a lo grotesco, que en Friedrich Schlegel se caracteriza por "la mezcla de lo heterogéneo, la confusión, lo fantástico e incluso, podríamos decir, algo parecido a un extrañamiento del mundo" (Kayser 2010, p. 92). En sórdida cercanía con lo irónico, lo grotesco prorrumpe en la confluencia contradictoria y salvaje de insolubles heterogeneidades. Así se enuncia en el fragmento [305] del Athenaeum “(...) lo grotesco juega con la inversiones peregrinas entre forma y materia, ama lo fortuito y raro, y en cierto modo coquetea con el arbitrio incondicionado" (Schlegel 2009, p. 133). ${ }^{7}$ Forma de heterogeneidad aberrante, retornará con Baudelaire como síntoma indeleble de la experiencia estética moderna, aunque posee ya en Schlegel el aura de una anomalía inquietante que sin embargo devela, en su abrupto restallar, la verdad de lo inefable en todo aquello que tiene de insoportable e infinito. "En la inquietante naturaleza de lo grotesco se manifiesta para Friedrich Schlegel el secreto más profundo del ser; y con ello el concepto adquiere un nuevo significado" (Kayser 2010, p. 92). Esta amplitud de su referencia se inscribe como atroz urdimbre de ironía, humor caricaturesco y drama trágico. La imposibilidad que afecta al héroe moderno, la trasmutación que impera sobre lo trágico, se traman en la nueva época como ambigüedad indecidible. El grotesco es la emanación misma de esta sobredeterminación formal, el elemento crujiente en el que lo trágico no puede asumirse sin el contrapunto de la risa burlesca, de la bufonada trascendental. "La caricatura es una combinación pasiva de lo ingenuo y lo grotesco. El poeta puede servirse de ella tanto de un modo trágico como cómico" (Schlegel 2009, fr. [396] p. 168). O como afirma Kayser, "lo grotesco es la caricatura desprovista de ingenuidad” (Kayser 2010, p. 94). La fusión y confusión de lo heterogéneo cristaliza en el "caos gris", a la vez que "ridículo" de la tragicomedia.

7 Cfr. fragmentos [75] y [389] de la misma obra. 
En segundo lugar, a la belleza medusea le es inherente una nueva temporalidad. No ya la severidad y armonía que se mimetiza con lo eterno, sino la caducidad permanente de lo que se pierde, se sustrae, se evapora en la fantasmagoría difusa y lábil del instante. La exigencia de hacer lo nuevo constituye el frágil contour de lo interesante.

A todo gran artista original suele aquí seguirle, mientras la corriente de la moda todavía lo eleve, un incontable enjambre de los copistas más mezquinos, hasta que sus eternas repeticiones y deformaciones hayan convertido el gran modelo en tan cotidiano y repulsivo que en lugar del endiosamiento surge el horror o el olvido eterno. La falta de carácter parece ser el único carácter de la poesía moderna; la confusión, lo común de su conjunto; la anarquía, el espíritu de su historia; y el escepticismo, el resultado de su teoría (Schlegel 1995a, p. 63).

Lo nuevo deviene el significante vacío en el que se decide por anticipado toda disyuntiva posible. Es el ser o no ser del imperativo de la moda. “¿Es nuevo, o no es nuevo? He aquí lo que preguntamos cuando estamos ante una obra, tanto desde el punto de vista más elevado, el de la historia, como desde el más vulgar, el de la curiosidad" (Schlegel 2009, fr. [45] p. 68). A la esencia eternamente provisoria de lo interesante le concierne en su consumación, la glorificación de lo efímero en la exaltación de la moda como ponderación sin reservas al huidizo y esquivo dios de lo actual.

\section{3. La modernidad}

"Su olor nauseabundo se mezclaba con el perfume de su piel impregnada de sándalo. Yo quiero que haya una amargura en todo, un ahogo eterno en medio de nuestros triunfos, y que hasta en el entusiasmo se halle la desolación. Esto me recuerda Jaffa, donde al entrar sentí el olor de los

limoneros junto con el de los cadáveres, el cementerio hundido dejaba ver los esqueletos medios podridos, mientras que los arbustos verdes balanceaban sobre nuestras cabezas sus frutos dorados."

(Gustave Flaubert. En Praz 1999, pp. 71-72)

Poco más de medio siglo separa la elucubración romántica de Friedrich Schlegel de la fecha de publicación de Las flores del mal. Un halo de aquella sensibilidad aún palpita como rancio perfume en Baudelaire. Los destellos antaño innovadores encuentran una resonancia inesperada bajo un nuevo contexto. La belleza estallada, incapaz de proscribir la fealdad que la sustraiga de su escena execrable, se entrega a una reviviscencia vigorosa al 
tiempo que fascinante. Iridiscencia hormigueante en el resplandor de lo corrupto, la belleza se somete a la temporalidad del relámpago que reverbera en intersticios fragmentarios. Trabajo incesante sobre las formas que decanta en sofisticación, en lo grotesco y en la moda, entrega entusiasta y sin reservas al fulgor de la novedad. Sin embargo, pensar en continuidad resultaría engañoso. ${ }^{8}$ El efecto óptico de quien observa fascinado solamente la espuma de las cosas, mientras entumece la atención respecto de todo aquello que habite la periferia del campo visual. Esa es justamente la operación que Baudelaire y su época, se proponen invertir. El ansia por capturar lo precario y transitorio en su vivo germinar, al tiempo que se experimenta el vértigo producto del continuo resquebrajarse de la subjetividad prepotente o interesante. Lo que se anhela es el agridulce aglutinante de lo heterogéneo, a la vez, refinado y mordaz, del "olor de los limoneros" embebido del hedor de "los cadáveres". Un movimiento ahogado contra sí mismo que capta Flaubert en su aspiración paradójica e indisoluble al entusiasmo y la desolación, al triunfo y a la amargura.

El desarrollo del capitalismo decimonónico a escala global y su consecuencia, la explosiva expansión de una ciudad en incesante borradura y creación, constituyen una experiencia singular absolutamente impensable para los parámetros anteriores. ${ }^{9}$ Sin la experiencia que la ciudad horada en sus habitantes no es concebible el acaecimiento de lo moderno. ${ }^{10}$ La moderna experiencia estética en Baudelaire se perfila en la emanación de

$8 \quad$ El excelente libro de Mario Praz posee el contrapunto negativo de un abuso en la perspectiva continuista que hace de Baudelaire -"el poeta en quien la Musa romántica destiló los venenos más exquisitos"- el punto de llegada en el que se consuman las figuraciones románticas. Esta perspectiva hace de lo romántico prácticamente sinónimo de la literatura del siglo XIX. Paul Valéry -quizá por motivaciones que guardan un íntimo interés con su propia posición poética-, por el contrario, ve en Baudelaire al poeta antagónico respecto de los románticos. Lo que la poesía romántica determina en Baudelaire es la negación. "El problema de Baudelaire podía ser pues -debía, pues- plantearse así: «Ser un gran poeta, pero no ser Lamartine, ni Hugo, ni Musset.» Baudelaire tiene su genealogía más bien en Poe que para Valéry posee, más allá de las apariencias, una poética divergente respecto del Romanticismo. "Las flores del mal no contiene poemas históricos ni leyendas; nada que se apoye en un relato. No vemos allí tiradas filosóficas. La política no aparece. Las descripciones son raras y siempre significativas. Pero todo es encanto, música, sensualidad potente y abstracta... Lujo, forma y voluptuosidad" Valéry 2010, pp. 47 y 57).

$9 \quad$ "Los historiadores del arte han observado que el surgimiento del arte moderno era principalmente un fenómeno urbano" (Gay 2007, p. 38). Confróntese este ensayo para un desarrollo más fino y detallado de los condicionantes históricos y sociales del arte moderno, principalmente de las vanguardias.

10 Como bien señala Habermas, cabe destacar el uso en sentido cronológico del sustantivo modernidad de la cristalización tardía que adquiere a mediados del siglo XIX. "Aunque el sustantivo «modernitas» (junto con el par de adjetivos contrapuestos «antiqui/moderni») venía utilizándose ya desde la Antigüedad tardía en un sentido cronológico, en las lenguas europeas de la Edad Moderna el adjetivo «moderno» sólo se sustantiva bastante tarde, a mediados del siglo XIX, y ello ocurre primero en el terreno de las bellas artes. Esto explica por qué la expresión «modernidad», «modernité», ha mantenido hasta hoy un núcleo semántico de tipo estético que viene marcado por la autocomprensión del arte vanguardista." (Habermas 2013, p. 18). 
una urbe en la que hormiguea la masa y, por lo tanto, el encuentro o el desencuentro son mediados por el azar y el anonimato. La primacía de la moda no es otra cosa que un sistema de referencias que funciona sobrepuesto al fondo monocromático de esta anónima indiferencia. El artificio de una jerarquía que subroga, el elemento suntuario del nombre, por la sonoridad fantasmagórica de la marca. Pero también, la futilidad de un texto que devela la continua mutabilidad de la articulación del tiempo respecto de la belleza en la excepcional legitimidad del presente. La moda deviene instantánea referencia al prestigio en medio del magma ectópico de la multitud. De ahí que a pesar de su presunta cercanía en la confluencia de ciertas temáticas o interpelaciones recurrentes, el límite que encuentra Schlegel para atribuirle otra dimensión a la fealdad, a lo bello supeditado al tiempo, al tedioso trascurrir de la moda es, justamente, lo interesante. El caos y toda dispersión se proyectan hacia la centralidad esquiva y en fuga permanente de la subjetividad irónica. En su presunto absoluto persiste, para el irónico, el centro imaginario de todo laberinto posible. Entonces, el desequilibrio y lo infinito encuentran siempre su mesura y su quicio en la gravitación vacua de esta subjetividad. Por el contrario, aquello que Flaubert enuncia no es solamente la concreción de un sintagma en el que confluyen índices de signos opuestos que encuentran o encontrarían su síntesis en la pertinencia de una subjetividad que los abarca. Lo moderno nace, paradójicamente, en el cenit de un lirismo pesimista que es la marca de una doble sustracción. Por un lado, desintegración de la estabilidad de las formas clásicas, y por el otro, labilidad de un sujeto que habita el corte en el que lo actual llama a una decisión imposible ya de prorrogar. Asombra que la experiencia estética de lo moderno en Baudelaire encuentre su punto óptimo de maceración en el contrapunto necesario de una espiritualidad decadentista. El acaecer de lo nuevo que en él se devela como la quintaesencia de lo moderno, es el resplandor vaporoso que en un instante se recorta sobre el miasma de lo muerto. La originalidad y novedad radica en el estupor de una época que asume de forma compulsiva y fanática la coalescencia entre el "agotamiento de las fuerzas y el pesimismo radical" y una "extraordinaria capacidad de novedad, de libertad radical" (Ritvo 2006, p. 183). Sin este escándalo en la ligadura de lo heterogéneo, lo nuevo dejaría de percibirse como un salto cualitativo, permanecería sometido al sopor ordinario de la mera cronología. 
Lo que Baudelaire aprehende es una nueva configuración entre belleza y tiempo, que se decanta de la interpelación por la posibilidad misma de la belleza en un mundo donde la actualidad deviene lo decisivo. Sin la sutura del duelo ni el adherente vigor de lo interesante, lo bello es un destello presente ante el fondo de un ideal que se desploma. A ese cuerpo centelleante y efímero de la belleza es a todo lo que modernamente podemos aspirar. Por eso, no es por mera frivolidad o esnobismo que la mirada insista en la vil carnadura de un arte menor. En la supuesta minoridad enraíza lo vivo en la temporalidad del acontecer. Ahora bien, sea marchito o degradado el medium artístico donde se cristaliza, toda belleza que resulte significativa se sostiene como exhalación viva de lo presente. La belleza general del arte clásico posee la hipertrofiada pesantez de un ilustre cadáver. Belleza distante, se goza en el gélido hieratismo de la historia. Sólo la mirada que interrumpe la asfixia histórica y revive la presencia sofocada en la obra es capaz de hacerle auténtica justicia. "El pasado es interesante no sólo por la belleza que han sabido extraerle los artistas para quienes era el presente, sino también como pasado, por su valor histórico. Lo mismo pasa con el presente. El placer que obtenemos de la representación del presente se debe no solamente a la belleza de la que puede estar revestido, sino también a su cualidad esencial de presente" (Baudelaire 1996, pp. 349 -350).

Si para Baudelaire lo esencial es lo circunstancial, es porque la fruición de lo bello solamente se consuma en el instante de la presencia. En él radica el máximo de intensidad que luego inicia su lenta disipación. Una agonía que declina inexorablemente en rutina e indolencia. Pero en el instante, la espontánea incandescencia del placer se fusiona con la creación. Toda creación se escande en su propio tiempo histórico. Hacer justicia a bellezas pasadas es admitir el carácter histórico de toda belleza, incluso contra la misma historia que al censurar el origen circunstancial y fortuito de lo bello, lo divisa como la inalcanzable eternidad pétrea del ideal. El tiempo es tan inherente al placer de lo bello que incluso configura al devenir de lo vivo hasta en los más exiguos y particularísimos detalles. "La idea que el hombre se hace de lo bello se imprime en toda su compostura, arruga o estira su traje, redondea o ajusta su movimiento, e incluso penetra sutilmente, a la larga, los rasgos de su rostro. El hombre acaba por parecerse a lo que querría ser” (Ibid., p. 350).

La moda se inscribe en esta falta de fundamento, pues la identidad es desde siempre un después. Ella coagula identidades parciales y vacías en la factoría adorable del artificio. 
Promete, en los estertores de esta alienación, una felicidad difusa que no puede más que desvanecerse una vez que acaba por concretarse. La moda comparte con la espiritualidad decadentista una eufórica obsolescencia que, paradójicamente, se desahoga en lo fragmentario y ruinoso; pues si la forma se configura en el punto de intersección de polaridades heterogéneas no sintetizables, como lo son la de lo actual y lo eterno, ésta simultáneamente a su concreción en el eje del presente no puede sino que descompletarse desde la perspectiva de la eternidad. Su tinte efímero y caduco en la pendiente de la desintegración convive con la soberbia luminiscencia que aspira ridícula y estúpidamente a sustraerse de la muerte. Esta tensión opera sobre la forma, que culmina por desplomarse al mismo tiempo en que se realiza. ${ }^{11}$

La fórmula es bien sabida. La belleza es un ser mixto, doble, bifronte. Posee una evidente composición dual, aunque se percibe equívocamente como unidad.

Lo bello está hecho de un elemento eterno, invariable, cuya cantidad es excesivamente difícil de determinar, y de un elemento relativo, circunstancial, que será, si se quiere, por alternativa o simultáneamente, la época, la moda, la moral, la pasión. Sin ese segundo elemento, que es como la envoltura divertida, centelleante, apetitiva, del dulce divino, el primer elemento sería indigerible, inapreciable, no adaptado y no apropiado a la naturaleza humana (Baudelaire 1996, p. 351).

La belleza eterna en su estado puro, es decir, separado y sin mezcla, resulta inhumana. Un enigma más proclive a la experiencia mística de lo inefable que a la experiencia estética de lo bello. Su existencia resulta análoga a la del eco, un fondo de plenitud que actúa como promesa que se sustrae, pero que simultáneamente deja siempre un resto como suplemento entramado en lo visible. Un señuelo hilvanado al conglomerado de las contingencias que sólo adquiere configuración interpretable como consecuencia del deseo, del apetito y de la pasión que sabe suscitar en el ahora. Al goce estético le es inherente una experiencia del tiempo, por lo tanto, no hay belleza que no devenga caída, el

11 La forma está habitada por un inmanente principio de podredumbre del que emerge su poder poético embriagador. De ahí que el arte y la literatura sean incluso más significativas que la realidad en su regularidad ordinaria. Puesto que condensan en la fragilidad del instante la sensualidad de lo vivo como contraste de la morbidez aplastante de lo sempiterno. "Jamás he visto un niño sin pensar que se convertiría en un anciano, ni una cuna sin imaginar una sepultura. Contemplar una mujer desnuda me hace imaginar su esqueleto. Por eso me entristecen los espectáculos alegres, y las escenas tristes me conmueven poco. Lloro demasiado por dentro como para derramar lágrimas al exterior, una lectura me emociona más que una desdicha auténtica" (Flaubert 2003, p. 24). 
saturnino declinar de una temporalidad que inevitablemente corroe la escena la carne. Sensibilidad clavada a la existencia del cuerpo y a las escansiones de su degradación. Sin este decaer no es concebible placer estético alguno. La fruición de lo bello moderno converge hacia el ocaso. Hacia el instante en el que la presencia aún retarda su evanescencia como inasible duración. Placer que se muestra, entonces, inseparable de la pérdida.

Lo invariable en la belleza se encuentra, en Baudelaire, sometido a lo decisivo que se juega en el instante. La nebulosa de las circunstancias configura una forma en el límite mismo en que resulta investida por un deseo singular en un punto del tiempo particular. La creación reúne en ese punto el umbral óptimo en el que la forma se concreta como estridencia de placer y refinamiento. Es esta alquimia la que palpita como supervivencia en todo arte del pasado. Si el arte antiguo puede ser salvado al margen de todo valor histórico, es porque lo habita una experiencia particular de la belleza, "calcada de las mismas circunstancias", que persiste inscripta en la idiosincrasia de su composición como aquello que el artista ha extraído a lo vivo en la irrepetible espontaneidad del instante presente. La modernidad aparece a los ojos de Baudelaire como la conciencia de una época que se entrega sin reservas a la inestabilidad de lo transitorio como ámbito único y excepcional para lo auténtico. La fugaz autenticidad es lo que la modernidad repite como "pasado auténtico de una actualidad futura". Por eso lo moderno no es una mera oposición respecto de lo clásico en tanto que categoría estética. Lo moderno es el parasitismo de lo clásico que lo transforma retroactivamente. "La modernidad se acredita como aquello que en algún momento será clásico; «clásico» sólo puede ser en adelante el «relámpago» del alza de un nuevo mundo, que, ciertamente, no puede tener consistencia sino que con su primera aparición también sella ya su propio hundimiento" (Habermas 2013, p. 19).

Trepidación convulsa entre alza y hundimiento, lo moderno en Baudelaire fermenta bajo una morbidez decadentista. De este modo, toda euforia revela una vitalidad exangüe como reverso indiviso a la vez que sombrío. Reflejo del pesimismo de una época que, sin embargo, se entrega a la vehemencia de la embriagues como medio exclusivo para aminorar su hastío. Furtivos éxtasis en los intersticios de un cuerpo exhausto, lo nuevo deviene el bálsamo, tal vez el narcótico, ante el vértigo de una espiritualidad resueltamente ambivalente. La lengua decadentista, como enuncia Huysmans, resulta una alambicada 
osificación que se determina por su "aroma de flores silvestres" y por "su color de carne de venado entreverada" (Huysmans 2012, p. 106). Incluso el culto de la ruina y del fragmento son consecuencias de su patológico refinamiento. Théophile Gautier definía el elemento bello en Las flores del mal como "fosforescencia de la podredumbre". Un estilo de decadencia que irrumpe en una sociedad que inevitablemente ha envejecido, al tiempo que cree haber alcanzado la cumbre de su civilización. ${ }^{12}$ Es, por lo tanto, un fenómeno de extrema madurez que se da como correlato de este movimiento encontrado, contradictorio, abigarrado. Hay un término que se acuña en la literatura de la época, desde Huysmans a los Goncourt, que condensa en forma inequívoca la singularidad irreductible de esta configuración de lo bello. Mario Praz lo señala remitiendo a un texto exquisito de Jules y Edmond de Goncourt.

La pasión por las cosas no proviene de la bondad o de la belleza pura de estas cosas, sino que proviene especialmente de la corrupción. Se amará locamente a una mujer, por su putería, por la maldad de su espíritu, por la perversidad de su cerebro, de su corazón, de sus sentidos; se apreciará el sabor descompuesto de una manduca por su olor fuerte y pestilente. En el fondo, lo que hace al apasionamiento es el hedor (faisandage) de los seres y las cosas (Praz 1999, p. 112).

Lo corrupto es lo que excita en lo bello. A través de la mediación carnal que opaca lo puro en la belleza, ésta queda retenida más acá de su invisibilidad. Así, se le concede un cuerpo para que acceda a concretar su imagen. De este modo, se visibiliza pero al precio de su degradación. La pasión se enerva como floración que vaporiza el perfume acre de los seres y envuelve al cuerpo deseante en la coloratura corpuscularia de lo bello. Lo faisandé es la apoteosis de esta decrepitud suspendida. La alegoría de lo nuevo como bella intumescencia que glorifica la poética decadentista. De la descomposición como síntoma de la abrasión del tiempo en los cuerpos, que a la vez que adultera, metamorfosea los objetos en reliquias fascinantes. Residuo y voluptuosidad, lujo de adiposa putrefacción. "Ni crudo ni cocido, «pasado». Lo faisandé (...) es aquello que, llevado a un punto de maceración que se confunde con un punto de descomposición, no alcanza aún el estado de podredumbre. Lo

12 Paul Bourget enuncia, respecto de Baudelaire, esta misma idea de nacimiento tardío no exenta de un paradójico regodeo en su cualidad crepuscular y senil. "Se ha dado cuenta de que llegó tarde a una civilización que envejece y, en lugar de deplorar este llegar tarde, como La Bruyère y como Musset, se regocija y hasta diría que se enorgullece. Fue un hombre de la decadencia y se hizo un teórico de la decadencia. Este es acaso el rasgo más inquietante de esta inquietante figura" (Bourget 2008, p. 90). 
«pasado» es dominado por una función temporal: está ya a punto de podrirse, pero aún no, todavía está en ese lugar que es, a la vez, la perfección última y el comienzo del decaer” (Ritvo 2006, p. 190). Indigesto fárrago de finalidad y comienzo, resplandece por un instante inconmensurable en su máxima perfección. Como lo añejo en el vino o la descompuesta sofisticación del queso azul, el refinamiento de la forma literaria explota en los intervalos de una delicuescencia interrumpida. Sólo cuando ella logra exhibir la perdida que la habita y la roe desde dentro, adquiere esa vibración encantada y vehemente que la torna verdaderamente significante. Esta intrínseca consustancialidad al tiempo, hace de la forma, algo indivisible del contenido. El contenido de la forma es la forma del contenido. La sobredeterminación de una singularidad mortificada en la absoluta particularidad del instante. "Hay, efectivamente, una mística de lo faisandé: cuando algo comienza a pasarse, entonces, justo en ese momento y no en cualquier otro, justo en ése (subrayo el valor del instante), algo de la intimidad de la materia se revela al lector; se revela la presencia de lo muerto en lo vivo, de lo mecánico en lo orgánico" (Idem.).

Esta sujeción al instante hace de la forma decadente una poética adecuada para el artista moderno. Para Huysmans, el escritor de los tiempos modernos se encuentra ante una encrucijada semejante a la de los poetas latinos de la decadencia. Pues la pestilencia que anuncia la descomposición social, contagia consecuentemente a la forma literaria, pero paradójicamente esta desintegración también propicia el fermento en que se sazona lo nuevo como acontecimiento disruptivo en la continuidad de la lengua. ${ }^{13}$ En tanto que hijo espiritual de Baudelaire ${ }^{14}$, para Huysmans, el artista moderno debe ante todo encontrar la originalidad, elevándose desde las ruinas exhaustas de los modelos clásicos y manidos de

13 "El interés que Des Esseintes sentía por la lengua latina no decaía en absoluto al llegar a esta época, en la que esa lengua se encontraba casi completamente descompuesta, y con su cuerpo colgando, como un animal descuartizado que está perdiendo sus miembros y exudando pus, y conservando en medio de la corrupción general algunas partes sanas que los escritores cristianos iban recogiendo a fin de adobarlas en la salmuera de su nueva lengua." Huysmans 2012, p. 160).

14 En $A$ contrapelo Huysmans pretende escapar a la trama trillada de la novela naturalista. Baudelaire será el faro estético de la nueva propuesta literaria. En este sentido debe leerse la sacralización que Des Esseintes, el extravagante personaje de la novela de Huysmans, hace del poeta. El final del primer capítulo resulta revelador. "Finalmente, sobre la chimenea, revestida de tela que había sido cortada del suntuoso tejido de una dalmática florentina, aparecía, entre dos custodias de cobre dorado y de estilo bizantino que procedían de la antigua Abadía de Bois-de-Bièvre, un maravilloso canon de iglesia, en forma de tríptico, cuyos compartimentos, separados y labrados como una labor de encaje, contenían, bajo el cristal que los recubría, tres poemas de Baudelaire, copiados sobre un auténtico pergamino con admirables letras de misal y espléndidas iluminaciones: a derecha e izquierda, los sonetos titulados «La mort des Amants» $\mathrm{y}$ «L'Ennemi», $\mathrm{y}$, en el centro, el poema en prosa que lleva por título «Any where out of the world» («A cualquier sitio, fuera del mundo»)" (Ibid., pp. 136 - 137). 
literaturas pasadas. Retorciendo, pervirtiendo, los temas y la forma, violentando la sintaxis con el anhelo de alojar lo extraño, que es siempre primicia de lo nuevo. Cultivando una sensibilidad sutil y despótica como intento de huida ante el hundimiento de la conciencia en la inercia de una sociedad desencajada.

Lo nuevo, entonces, supura entre la porosidad epidérmica de un cuerpo en tránsito permanente. Reverdece en el parpadeo de una luminiscencia que se retira del vértigo sincopado de materias en disgregación. Así, la novedad reverbera como una veladura lábil, aunque decisiva, una laminilla que se deshace en la superficie de las cosas. Desde ahí, hace señas al observador atento, "príncipe que disfruta en todas partes de su incógnito" (Baudelaire 1996, p. 358), al que induce a demorarse en el placer sinestésico y efímero de la oscilación presente. El artista moderno debe responder intrépidamente a esta demanda. Pues en ello le va su ser auténticamente moderno. Sin esta consustancialidad con lo efímero, la belleza desaparecería sin dejar rastro. Anónima aurora sin testimonio de su brillar, se ocluiría sordamente en la nada. Por eso, Baudelaire defiende y estimula esa veloz agilidad de ejecución en Constantin Guys. Una ligereza que se muestra típica de todo arte menor, en tanto que "(...) hay en la vida trivial, en la metamorfosis cotidiana de las cosas exteriores, un movimiento rápido que impone al artista la misma velocidad de ejecución" (Ibid., p. 353). Esta ligereza es signo de la irreductible heterogeneidad que conlleva la búsqueda de lo nuevo respecto de cualquier pretensión de clásica fijeza. Pero si bien, la resuelta ejecución es aquello que toda circunstancia amerita, en última instancia su abordaje precisa el contrapunto necesario de un elemento narrativo y crítico, a través del cual, ella pueda depurarse de todo dato que devenga irrelevante, y procurar evocar, en la dilación de su duración material, un anhelo de eternidad.

No sorprende, entonces, que el artista de los tiempos modernos, en concordancia con la belleza que debe captar, sea él mismo un ser mixto. Este carácter híbrido, dividido y compuesto, es una marca excepcional que Valéry destaca en Baudelaire. En él confluye la "inteligencia critica" y la "virtud poética", mezcla que se perfecciona en la recepción que éste hace de la escritura de Poe. ${ }^{15}$ Esta ambigua dualidad es incluso parte sustancial de

15 "El demonio de la lucidez, el genio del análisis, y el inventor de las combinaciones más nuevas y más seductoras de la lógica con la imaginación, del misticismo con el cálculo, el psicólogo de la excepción, el ingeniero literario que profundiza y utiliza todos los recursos del arte, se le revelan en Edgar Poe y lo maravillan. Tantas visiones originales y promesas extraordinarias lo fascinan. Con ello su talento se transforma, su destino se modifica magníficamente." Valéry 2010, p. 46). Paul Bourget se expresa en la 
aquello que se revela en lo faisandé. Por un lado, la imagen fija, muerta fascinación de lo instantáneo y, por el otro, la disgregación continua en la duración que no cesa en cumplir su decaer. En esta alternancia, lo corrupto digiere la belleza como grácil encabalgamiento de melancolía y voluptuosidad. Baudelaire concibe la belleza bajo esta amalgamada duplicidad.

Tiene algo de ardiente y de triste, algo un poco vago, que deja espacio para la conjetura. Si se prefiere, voy a aplicar mis ideas a un objeto sensible, al objeto, por ejemplo, más interesante en la sociedad, a un rostro de mujer. Una cabeza seductora y bella, quiero decir, una cabeza de mujer, es algo que hace soñar a la vez -mas de una forma confusa- en la voluptuosidad y en la tristeza; que comporta una idea de melancolía, de laxitud, incluso de saciedad - pero a la vez una idea contraria, es decir, un ardor, un deseo de vivir, asociado a un reflujo de amargura, que proviniera de privación o desesperanza. El misterio, la añoranza, son también caracteres de lo bello (Baudelaire 1995, pp. 24 - 25).

Las resonancias con nuestro epígrafe de Flaubert son notorias y evidentes. Una coloratura delirante, como de carne quemada, lo tiñe todo con la densidad del hastío. El Spleen y la melancolía constituyen el fondo monótono e inquebrantable que parasita el resplandecer momentáneo y fugitivo, es decir, esencial, de lo bello. "Yo no pretendo que la Alegría no pueda asociarse con la Belleza, pero sí afirmo que la Alegría es uno de los adornos más vulgares; mientras que la Melancolía es, por así decirlo, su ilustre compañera, hasta el punto de que no concibo (¿Será mi cerebro un espejo hechizado?) un tipo de Belleza en que no entre la Desgracia" (Ibid., p. 25). Entonces, la mujer para la sensibilidad decadentista sólo puede ser bella si condensa, en forma indivisa y abigarrada, la deidad y la prostitución. La femme fatal aparece como la fantasmagoría que cristaliza un objeto ardiente como aglutinante de deseo irresistible y de perversión criminal. Su prototipo será esa "Salomé sobrehumana" que Des Esseintes (el personaje de la novela de Huysmans) imagina, tanto más real cuanto más deseada, en las obras de Gustave Moreau.

Y ya no era únicamente la bailarina provocativa que logra despertar en un anciano el deseo y la apetencia sexual con las disolutas contorsiones de su cuerpo; que consigue doblegar el ánimo y disolver la voluntad de un rey balanceando los pechos, moviendo frenéticamente el

misma dirección. "A través de tantos extravíos en los que la sed de una infinita pureza se mezcla al hambre devoradora de los placeres más ardientes de la carne, la inteligencia del analista permanece cruelmente dueña de sí. El misticismo, como el libertinaje, se codifica en fórmulas en el cerebro que descompone sus sensaciones con la precisión con que un prisma descompone la luz” Bourget 2008, p. 72). 
vientre y agitando temblorosamente los muslos, sino que se convertía, de alguna manera, en la deidad simbólica de la indestructible Lujuria, en la diosa de la inmortal Histeria, en la Belleza maldita, escogida entre todas por la catalepsia que le tensa las carnes y le endurece los músculos; en la Bestia monstruosa, indiferente, irresponsable, insensible, que corrompe, del mismo modo que la antigua Helena, todo lo que se le acerca, todo lo que la mira, todo lo que ella toca (Huysmans 2012, p. 179).

La belleza no sólo es corrupta, también lo corrompe todo. El artista es víctima y victimario de esta abyecta divinidad. Movido por la embriaguez, su pasión insiste en el cultivo insaciable de su ritual maldito. Pero, lo propio del artista moderno es reservarse la potestad de una última decisión. Suspender el éxtasis para devenir activo en la creación de una forma. Pues se trata de producir, en el tiempo propicio, el corte óptimo en el revuelto de los elementos para que en el restallar del instante, éstos adquieran su composición más significante y perfecta. De este modo, se devuelve la impresión de lo inmediato como correlato de la mediación de la experiencia. En ello estriba el placer del flâneur. Hecho de emociones agitadas, su poética tiende a excederse en la potenciación de los extremos. Ansía el shock y lo perverso, adora lo nuevo bajo la sombra de la una lucidez estetizada que tiende irreversiblemente hacia el declive. El decadente, como el dandi, que por lo demás no deja de ser un género de su especie, descree del mundo al que considera algo sucio, irremediablemente depravado, pero contradictoriamente se arroja a una soteriología audaz cuya fe pueril se sustenta en una doctrina del arte como salvación. El arte aparece como el último resguardo de los valores antiburgueses. La costra gloriosa que aún sirve de refugio y bastión para lo auténtico. Por eso mismo, el único valor posible reside en la originalidad. Pues ser original es consustanciarse con lo nuevo. Ser su suplicante y su cultor.

La autenticidad se manifiesta como fidelidad al tiempo, por lo tanto, designa el estado en el que el sujeto queda sumergido en el torbellino incoherente que es la vida externa de un siglo. Bajo esta tesitura, la flânerie se muestra, a primer momento, como un modo receptivo. Se trata de moverse en lo que se mueve, captar lo que el tiempo viene a sellar en forma indeleble en las sensaciones. La originalidad se consigue habiendo digerido la multiplicidad de escorias circunstanciales que la ciudad expulsa como excedente vital en la profusión de sus días. Por eso Baudelaire estimula el orden de sucesión que promueve el Sr. G. en su trabajo; primero hay que "contemplar la vida" y sólo más tarde encontrar los 
medios adecuados para expresarla. A costa de mirarlo todo se depura lo fundamental. Esta purificación de la impresión se realiza por mediación de la memoria como sedimento de la experiencia. Algo se inscribe siempre sobre el soporte de la pérdida. La autenticidad reside en un diseño de la forma, en un artificio producto de fantasmagoría, y en el resguardo de una intensidad que le queda asociada como memoria atada a lo placenteramente presente. ${ }^{16}$ El artista moderno, en tanto que flâneur, es un animal de ciudad, simultáneamente maduro y pueril, se hunde en la multitud con la que se mezcla, pero en la que jamás desaparece, salvo por lapsos de tiempo voluntariamente controlados. Pues para él, multitud y soledad resultan "términos iguales y convertibles". "Quien no sabe poblar su soledad, tampoco sabe estar solo en medio de una atareada muchedumbre" (Baudelaire 2010a, p. 66). El paseo deviene un juego de fusiones y contrapuntos en los que el poeta goza la posibilidad de ser "él mismo y otro".

Ni crudo ni cocido, el Sr. G. habita el umbral de una maceración difusa y ambigua. Lo domina un elemento incivilizado, simultáneamente maduro e infantil, precoz y tardío, una pulsión bárbara que estimula constantemente su curiosidad. Ese barbarismo es el signo de una sensibilidad no embotada. A la vez, débil y soberana, deviene la marca de su genialidad. En contraposición al hombre civilizado, que al aturdir su cerebro con la acumulación de conocimientos, queda finalmente negado para percibir la novedad; la genialidad es, para Baudelaire, la infancia recobrada a voluntad. Como en Nietzsche, la valoración de la infancia va de la mano de una crítica a la hipócrita mascarada del hombre culto, que al develarse en su impostura, queda expuesto en su trivial verdad, eunuco al que la acumulación avasallante de la civilización histórica ha terminado por castrar. Por el contrario, el "niño que juega en confiada inconsciencia entre las cercas del pasado y el futuro" (Nietzsche 2003, p. 41) ${ }^{17}$, crea porque olvida y en esta inconsistencia alcanza, sin embargo, un rapto de felicidad. "El niño todo lo ve como novedad; está siempre embriagado" (Baudelaire 1996, p. 357). Convaleciente e infante, el artista moderno, se

16 "Se entabla entonces un duelo entre la voluntad de verlo todo, de no olvidar nada, y la facultad de la memoria, que ha adquirido el hábito de absorber vivamente el color general y la silueta, el arabesco del contorno" (Baudelaire 1996, p. 366).

17 La segunda intempestiva posee una clara empatía con la perspectiva decadentista. Lo que Nietzsche viene a denunciar, escandalosamente para los parámetros del racionalismo decimonónico, es un estado de impotencia vital íntimamente ligado al exuberante desarrollo del conocimiento histórico. La erudición historicista crea un estado de vigilia permanente que culmina por dañar todo lo vivo y con ello, la apertura hacia lo nuevo, lo futuro. El sentido histórico, al suprimir el olvido, clausura toda novedad posible Es por eso que, el peso asfixiante de la acumulación del pasado deviene, el sepulturero de todo instante actual o presente. 
"interesa vivamente por las cosas", reconoce el lívido borbotear de la vida en su singularidad, allí donde no se lo espera, en idéntico sitio donde antes hallaba la anémica rigurosidad de la existencia enclaustrada. De este modo, la curiosidad lo liga al afuera. Se diferencia así de lo interesante, que vive de la sustracción distante que establece sobre una otredad a la que finalmente aniquila. El artista moderno se adhiere a la multitud con toda la vehemencia de su pasión. "No todos pueden darse un baño de multitudes: gozar de la muchedumbre es un arte; y sólo puede darse un festín de vitalidad, a expensas del género humano, aquel a quien un hada insufló en su cuna el gusto por el disfraz y la máscara, el odio al domicilio, y la pasión del viaje" (Baudelaire 2010a, p. 66). Como si fuese un espejo de la muchedumbre, un "caleidoscopio dotado de consciencia", el artista se entrega, como "un yo insaciable del no yo", a la voluptuosidad que el encuentro con lo otro le promete, deseoso por hallar en el crepitar de los cuerpos, el halo lánguido y exótico que las calles ofrecen como ese fruto tanto más deseado cuanto más prohibido.

Finalmente, hemos dicho del dandi que era un género de la decadencia. Baudelaire lo define como el "último destello de heroísmo en las decadencias". Ya que su fisonomía es la de un ser "pasado", extemporáneo, la mezcla altamente equilibrada de "gravedad en lo frívolo". En el dandi la fe despótica en las virtudes del arte se ve proyectada sobre su persona misma. Por lo tanto, deviene obra viviente, la demostración concreta del anclaje de la eterna belleza en la molicie presente del cuerpo. "Estos seres no tienen otra profesión que cultivar la idea de lo bello en su persona, satisfacer sus pasiones, sentir y pensar. Poseen así, a su antojo y en gran medida, el tiempo y el dinero, sin los cuales la fantasía, reducida a estado de sueño pasajero, apenas puede traducirse en acción” (Baudelaire 1996, p. 377). El ocio y el capricho sintetizan ese lujo en que reside su subjetividad, resabio de una altanería irónica que juega permanentemente a la repugnancia de toda utilidad. En el ocio de sus días, se sumerge en un refinamiento despreocupado que intenta aprisionar el misterio de lo sensible, la agitación ansiosa en la que palpitan las más sutiles y ligeras modulaciones de lo nuevo. Pero ante todo, el dandi es un ser epigonal. Eterno habitante del ocaso, resulta un fenómeno tardío, intempestivo, un pasado que germina pestilencia, pero que simultáneamente interpela lo futuro a costa de resultar sistemáticamente indigerible para la tiranía de la media. "El dandismo aparece sobre todo en las épocas transitorias en las que la democracia no es todavía todopoderosa, en las que la aristocracia sólo está parcialmente 
vacilante y envilecida" (Ibid., p. 379). Es, por lo tanto, un injerto, un añadido que usufructúa su existencia de collage. Irrumpe en los intervalos, en el pastiche abyecto en el que los cuerpos se desbordan ante la inconsistencia de las formas y eyectan, incontenible, sus materias en descomposición. "El dandismo es un sol poniente; como el astro que declina, es soberbio, sin calor y lleno de melancolía" (Idem.) Perfecto estereotipo de las fantasías modernas y decadentistas, un epígono que irradia la belleza estilizada de su extenuada materia, como perfume de melancolía.

\title{
2. Alegoría y Ciudad
}

\author{
“¡París cambia!, ipero en mi melancolía nada \\ cambió de lugar! Palacios nuevos, andamios, bloques, \\ barrios viejos, todo para mí se vuelve alegoría, \\ y mis recuerdos queridos son más pesados que rocas.
}

(Baudelaire 2011, p. 231)

\section{1. La antinaturaleza}

La reactualización de la alegoría por parte de Baudelaire va de la mano de su experiencia de París. Se inscribe, por lo tanto, como un recurso imprevisto, hasta anacrónico, pero erigido paradójicamente en fundamento de una nueva lírica moderna. Lo alegórico se eleva sobre una doble sustracción. Huye tanto del "subjetivismo y simbolismo románticos", como de su corolario, una naturaleza entendida como orden imitable, como garante último susceptible de saldar toda pérdida de sentido y por lo tanto, objeto privilegiado, sino exclusivo, para toda nostalgia. Borrada en provecho del artificio, la naturaleza sobrevive como fantasma que retorna de su existencia negativa. Rechazada, deviene tanto más presente cuanto más intensamente negada. Como el mal, es el escándalo mismo de la presencia. La alegoría en Baudelaire vincula heterogeneidades, se percibe en la opacidad y el artificio de todo lo que cambia, y que por su mutar, acaba por desvanecerse.

Es el cambio de París, el moverse en lo que se mueve, lo que transforma el significado de la flânerie. El flâneur deviene otro en la misma medida en que su estado de 
embriaguez se torna receptivo de la novedad que la urbe arroja sobre él con cada renovado estertor de su cuerpo múltiple e infinito. La flânerie en Baudelaire es una experiencia del hallazgo y de la pérdida. Una borrachera que se hunde en la exhalación de la multitud, en $\mathrm{su}$ serpentear indefinido por pasajes y callejuelas. Su contrafigura es el paseante (promeneur) rousseauniano. Caminante abroquelado, "metido en su interior como un molusco", su perfil es el de un retorno a sí mismo sobre el trasfondo de una adecuación al orden eterno de la naturaleza como garante de lo bello, verdadero y bueno. Jean-Jacques se desplaza en el exterior para mejor reencontrarse en su movimiento interno. El afuera no es sino la ocasión, el punto de viraje desde el cual la ensoñación se precipita. Ella se consuma en el placer que se logra cuando el éxtasis viene a sellar un equilibrio parcial entre la vida anímica y los estímulos externos. De ahí que lo suyo sea un monólogo sólo interrumpido con malestar y como efecto involuntario de un accidente. ${ }^{18}$ En el comienzo de su segundo paseo Rousseau describe con precisión la significación de este doble desplazamiento.

Pues habiendo formado el proyecto de describir el estado habitual de mi alma en la posición más extraña en que mortal alguno podrá encontrarse nunca, no he visto manera más simple y más segura de ejecutar esta empresa que llevar un registro fiel de mis paseos solitarios y de las ensoñaciones que los llenan cuando dejo mi cabeza enteramente libre y a mis ideas seguir su inclinación sin resistencia ni traba. Esas horas de soledad y meditación son las únicas del día en que soy yo plenamente y para mí sin distracción ni obstáculo, y en que verdaderamente puedo decir que soy lo que la naturaleza ha querido (Rousseau 2008, p. $33)$.

En la soledad del entorno natural, donde reina una espontaneidad sin obstáculos, pues la mirada inquisidora del tercero inoportuno ha sido momentáneamente burlada, JeanJacques goza finalmente de un deleite secreto y no alienado. Encuentra que la sucesión de su orden interno y el del entorno natural, entran en una sinergia que se abstiene de todo displacer. Entonces, ciego para toda mirada humana, cree devenir él plenamente. Sin embargo, una alienación aún más radical y difusa reina en su existencia no percibida, como

18 Piénsese en el tragicómico suceso del segundo paseo en el que Jean-Jacques se ve violentamente despertado de su placentero ensueño por una exterioridad que se abalanza bruscamente sobre él en forma de perro danés. "Más o menos a las seis estaba en la pendiente de Ménilmontant, frente por frente casi del Galant Jardinier, cuando al echarse a un lado bruscamente y de pronto las personas que caminaban delante de mí, vi caer sobre mí un gran perro danés que lanzado a toda velocidad por delante de una carroza no tuvo siquiera tiempo de detener su carrera o de girar cuando me vio. (...) No sentí ni el golpe ni la caída ni nada de cuanto siguió hasta el momento en que volví en mí." (Rousseau 2008, p. 37). 
el germinar de una forma dual en la que el deseo como el deseo del otro cristaliza como presunta autenticidad del ser aprehendido sobre la base de una naturaleza idealizada a la vez que maternal. Pero más allá de su deseo, Rousseau ha tenido que lidiar permanentemente con la escisión -¿terceridad inoportuna?- entre naturaleza y civilización. Tal vez la motivación fundamental de su pensamiento, esa agitación que vive como tormento, haya sido lograr una sutura que cure el mal de una sociedad en desnaturalización creciente. Ahora bien, la estética moderna no ha hecho más que afirmarse sobre la herida de esta desnaturalización. En este sentido, Baudelaire se vislumbra como el culminar de una tradición que hunde sus raíces en una temprana reacción a Rousseau. "Al fracaso de la vuelta de la naturaleza sigue - de modo programático por primera vez en Baudelaire- el rechazo de una estética basada en la naturaleza en general. (...) La estética de la modernidad transforma el atrevido intento de una vuelta $a$ la naturaleza, en un giro contra la naturaleza. El arte deberá fundarse como antinaturaleza” (Jauss 2004a, p. 113). El arte moderno se afirma contra natura, en la gloria efímera y melancólica del artificio.

La pasión del artificio como antinaturaleza tiene su prematuro origen en el heterodoxo ambiente de la contrailustración. En Sade como afirmación egoísta ante Dios y toda moral en nombre de una naturaleza que se expresa en la pletórica indistinción entre creación y destrucción. Por lo tanto, como agente exclusivo del crimen, pues "no puede haber crimen contra la naturaleza”. El libertino al afirmar el crimen y su propia destrucción, "autoriza con ello contra su voluntad a la naturaleza para otra creación" (Ibid., p. 116). Se descubre finalmente como autómata de un impulso ciego al servicio aborrecible de una madre abominable y perversa. En Chateaubriand como reacción al concepto de naturaleza rousseauniano. El héroe sólo encuentra lo "bello y lo moral" en el marco de "una naturaleza corregida", de manera que se sacrifica "el acuerdo ingenuo del yo y la naturaleza en una reflexión sentimental" (Ibid., p. 117). El ennui es el precio a pagar por el desencuentro con una naturaleza que se hunde melancólicamente en el pasado.

Pero quién ha ejercido verdaderamente una influencia determinante en Baudelaire, sobre la base de un ataque virulento a los posicionamientos de Rousseau, ha sido Joseph de Maistre. En una carta de 1856 dirigida al fourierista Alphonse Toussenel, Baudelaire explicita esta filiación. 
¿Qué es el progreso indefinido? ¿Qué es eso de una sociedad no aristocrática? Creo que eso no constituye una sociedad. ¿Qué es eso de que el hombre es bueno por naturaleza? ¿Dónde se lo conoció? El hombre naturalmente bueno sería un monstruo, quiero decir un Dios. (...) ¡Y un hombre como usted! ¡Soltando al pasar, como mero redactor del Siècle, injurias para de Maistre, el gran genio de nuestro tiempo, un vidente! (...) Después de todo, las herejías a las que siempre hice alusión no son sino la consecuencia de la gran herejía moderna, la doctrina artificial que sustituye la doctrina natural, -quiero decir la supresión de la idea de pecado original. (...) Así la naturaleza entera participa del pecado original (Baudelaire 2005, p.50).

En de Maistre, Baudelaire encuentra la vieja degradación teológica de la naturaleza, aunque circunscripta, esta vez, a una coyuntura excepcional que pretende, simultáneamente, servir de fundamento a una estética moderna que no puede afirmarse de otro modo que como antinaturaleza. El asombro irrumpe ante la paradoja de que la rectitud teológica viene a reactualizar, en un mismo gesto, la herejía moderna. Al artificio le toca, entonces, ocupar el espacio abierto por esta degradación. El hueco vacante ante la caída irremediable del objeto primordial. En esta sustitución, marca la diferencia ante una escena cuya renuencia a lo diferente pretende solaparse en una ingenua comunión natural que se sostiene en "la supresión de la idea de pecado original'. En línea con Agustín, para de Maistre el pecado desata un maldito suplemento en el que no sólo se corrompe la primera pareja humana, sino que con ella se desmorona la totalidad de la naturaleza devenida ahora enferma laxitud, no exenta, por lo tanto, de maldad y fealdad. Bajo tal tesitura se vislumbra que lo bello no pueda ser comprendido de otra forma que como artefacto. Simulacro cuya legitimación resulta siempre lábil y conjetural. Una victoria por definición transitoria, pues se configura en el eclipse de toda referencia pretendida fija, susceptible de mostrarse, por lo tanto, de suyo evidente. Lo bello se decanta como una circunstancial determinación del gusto que por principio se muestra incapaz de mantener una distancia estable respecto de su negatividad, es decir, de aquello mismo que en su erigirse rechaza. "Baudelaire vio ahí la más profunda explicación del lado nocturno de la naturaleza humana, de donde se sigue que lo bello en la conciencia de la modernidad no puede encontrar su medida en lo natural, y menos en el ideal clásico de la ingenuidad. Más bien, esta naturaleza corrompida desde el principio, debe ser superada en lo estético y en lo moral por lo artificioso" (Jauss 2004a, p. 116). Ahora bien, el gesto de Baudelaire aporta el aditamento de un giro ambiguo que a la 
vez que lo torna más fascinante, puede incluso venir a herir bellas susceptibilidades. Como señala Jauss, consecuencia de esta filiación, es que Baudelaire inscribe a la naciente modernidad estética bajo un aura de clara "legitimación conservadora".

La reactualización de lo alegórico para una estética moderna debe leerse en el marco de esta desnaturalización y la consecuente afirmación del artificio. De ahí que la alegoría se vincule en Baudelaire con la experiencia febril de la ciudad. En este sentido, la metamorfosis no se limita únicamente a la acción de pasear, flânerie, sino que afecta, en tanto que naturaleza caída, al concepto mismo de paisaje. El paisaje (paysage) deja de remitir exclusivamente al entorno natural contemplado desde un punto de vista, por lo tanto, en el registro semántico de (pays) país comprendido como región, tierra, campo, de ahí el francés paysan, campesino. Él también deviene disfraz, se pervierte como paisaje urbano, como retrato de la multitud perdiéndose en la gravitación monstruosa de la vida anónima de la gran ciudad. Se torna panorama, objeto privilegiado del ojo simulado en la fotografía. Incluso y como fruición fetichista puede él mismo fingirse en diorama, especie de relicario moderno que simula el movimiento o el viaje a lo exótico, condensación de las fantasmagorías kitsch y sentimentales de la naciente civilización técnica. Como en Un bar aux Folies Bergère (Un bar de las Folies Bergère) de Eduard Manet, la alegría compulsiva esfuma los contornos hacia el brillo incandescente de una sociedad que goza en el fulgor del espectáculo, como simulacro de una felicidad que se anhela eterna, pero que resulta tanto más efímera y pueril, en la medida en que se procura hallada en la profundidad laminada del azogue o en la traslúcida fragilidad del cristal.

Trasmutación artificial bajo el trasfondo del pecado. Comunión satánica entre lo abyecto teológico y la jovialidad histérica de una nueva herejía moderna. Lo alegórico articula estas tensiones irreconciliables sobre el fondo de una belleza supeditada al fluir evanescente del instante. Estas heterogeneidades prosperan incluso hasta lo grotesco. ${ }^{19} \mathrm{Un}$ encabalgamiento de elevación y desplome se añade a la dinámica contradictoria entre

19 En Baudelaire lo grotesco no se limita al enrarecimiento de la forma que en la heterogeneidad de lo incondicionado se asume como el secreto más profundo del ser, sino que en él, lo grotesco, en tanto que inscripto en el marco de lo cómico general, se encuentra íntimamente ligado a la naturaleza caída. Reímos porque caemos y de aquellos que han caído. Hay un sentimiento de degradación que es intrínseco al humor. La diferencia entre lo cómico y lo grotesco es, en principio, de intensidad y de objeto. "Lo cómico es, desde el punto de vista artístico, una imitación; lo grotesco, una creación." Se vincula así al artificio. Si la risa expresa la idea de superioridad del "hombre sobre el hombre", lo grotesco lo hace "del hombre sobre la naturaleza" (Baudelaire 2001, pp. 99 - 101). 
tiempo y eternidad. Una carta sin fecha a Fernand Desnoyers, se torna la ocasión para que Baudelaire describa, cruda e irónicamente, la configuración de la nueva sensibilidad.

Usted me pide versos para un pequeño volumen, versos sobre la Naturaleza (...) Pero, ya sabe que soy incapaz de emocionarme con los vegetales (...) Nunca podré creer que el alma de los Dioses habite en las plantas y, aunque lo hiciera, me importaría poco y consideraría la mía propia mucho más valiosa que la de las legumbres santificadas. Incluso siempre pensé que en la Naturaleza, floreciente y rejuvenecida, había lago impúdico y penoso (Baudelaire 2005, p. 44).

La naturaleza es existencia mancillada, despojo vergonzante y espurio, sobrevive como resto de una degradación que es preciso reparar para poder hacerla tolerable. De ahí que lo natural deba ser superado en provecho de lo estético como el erigirse mismo del artificio sobre el vacío abierto por su caída. Ante el hundimiento del objeto primordial, el artificio captura la totalidad de la escena del ser. En las antípodas de lo romántico, el trastrocamiento alcanza el límite de su extravío en el hecho de que la naturaleza culmine imitando al artificio. "Después de las flores artificiales imitando con precisión la forma de las flores auténticas, buscaba ahora flores naturales capaces de reproducir la imagen de las flores artificiales y falsas” (Huysmans 2012, pp. 216 - 217). La herejía moderna consiste en aceptar este imperio del artefacto, sin que esto se reduzca a la simplicidad de lo fingido o ficticio. Barthes ha comprendido en este sentido la coloratura singular que devela el teatro en Baudelaire. Teatro sin teatralidad, hace que esta última, sin embargo, sumerja en sí misma la integridad infinita de la vida. ${ }^{20}$ Como si, liberada de su objeto presuntamente adecuado, la teatralidad desbordada, se diseminara ya por todas partes. En tanto que actor de sí mismo, ésta instala el artificio en el cuerpo, y la escena deviene la perturbadora fantasmagoría de un actor sin la limitación del teatro convencional. De este modo, el actor es la prostitución misma, la síntesis viviente de la totalidad de las permutaciones. Por lo tanto, tan artificial como las flores deseadas por Des Esseintes. "Así podemos adivinar que Baudelaire poseía el agudo sentido de la teatralidad más secreta y también más turbadora, la que sitúa al actor en el centro del prodigio teatral y constituye el teatro como el lugar de una ultraencarnación, en la que el cuerpo es doble, a la vez cuerpo viviente procedente de

20 “Qué es la teatralidad? Es el teatro sin el texto, es un espesor de signos y sensaciones que se edifica en la escena a partir del argumento escrito, esa especie de percepción ecuménica de los artificios sensuales, gestos, tonos, distancias, sustancias, luces, que sumerge el texto bajo la plenitud de su lenguaje exterior" (Barthes 2003, p. 54). 
una naturaleza trivial, y cuerpo enfático, solemne, helado por su función de objeto artificial" (Barthes 2003, p. 56).

Pena e impudicia, signos de una caída que vuelve irrisorio todo intento de correspondencia entre el yo y la naturaleza. Pues la erección de lo artificial es simultánea a la descomposición de la naturaleza orgánica. Pero esta desintegración de lo orgánico debe leerse en Baudelaire bajo una tonalidad decadentista, y de ninguna manera en el registro de una candidez confiada en el desarrollo utópico de la técnica o en la idea decimonónica de progreso indefinido. Se trata más bien de gozar del desmembramiento. De la belleza como juego que impulsa a la reconfiguración permanente de materias en putrefacción. En este sentido, y a propósito de Baudelaire, Paul Bourget esbozaba su teoría de la decadencia sustentada en la subsunción continua de los elementos por vía de la analogía. De la misma manera en que una sociedad se resuelve en federaciones menores, todo organismo lo hace en células. Al individuo le corresponde ser la célula social. La decadencia es la interrupción de la correspondencia integral y orgánica entre el todo y los partes. Por lo tanto, emerge cuando la energía de cada célula se independiza haciendo que el cuerpo orgánico finalmente se disloque. Como el resultado de una enfermedad autoinmune, la anarquía de las partes desangra la vida del todo. En este sentido, la salud del cuerpo social precisa la depuración del tipo vital del dandi, pues el lujo banal es en sí mismo el índice verídico de su cercano declive. En analogía con el ámbito social, un "estilo de decadencia” es aquel en el cual la unidad del libro se ve corrompida, carcomida por la dispersión de sus partes. La palabra se autonomiza a costa de la frase, el cuerpo orgánico del lenguaje deviene ruina. Amputada sonoridad fascinante, se recluye en la morbidez sustancial del artificio (Cf. Bourget 2008, p. 91).

Algo similar es visible en la pintura de la época. El trazo rápido y nervioso de la pintura impresionista se recorta de la imagen en provecho de la sensación. "La disolución del universo de la memoria en el vapor de las sensaciones, he aquí el primer espectro de la decadencia" (Ritvo 2006, pp. 205 - 206). En el impresionismo, la naturaleza es borrada del paisaje, no solo en beneficio de lo urbano, sino de algo que es como su atmósfera, su alma circunstancial, algo que estamos tentados a llamar evento. El evento es la irreductible actualidad que se resuelve en la bruma corpuscular que habita ese espacio indeterminado entre la superficie de las cosas y las percepciones del vidente. En ese sentido es novedad 
permanente, artificio cuya configuración accidental se decanta en pasado en el mismo instante en que se realiza. De ahí la repetición inane del motivo en Monet, todo el tema está en el fenómeno, en el estallido hormigueante de las formas ante el avasallante frenesí de la luz. Un paso más y el aislamiento reina sobre todo contexto, la palabra y la pincelada devienen objeto en la poética puntillista. Incluso, retorno de la naturaleza ironizada en vidrio en Émile Gallé. Cercenamiento del orden natural reconfigurado en cristales esmaltados. Fantasías de una naturaleza pre-adánica, bella hasta el dolor, encuentran su cita bufa y mordaz en una evocada organicidad que se desmiente continuamente en el espesor muerto de lo inorgánico, en la estéril mecánica de la sociedad industrial.

\section{2. La des-subjetivación}

El otro punto que sostiene lo alegórico contra toda estética romántica es la apuesta por un crepúsculo de la subjetividad. La putrefacción de la totalidad orgánica de la naturaleza no deja inmune a la presunta unidad subjetiva. El reino del artificio resulta efímero y fragmentado, heterogéneo respecto de toda síntesis unitaria susceptible de cristalizar en lo simbólico romántico. Baudelaire tendrá que adentrarse en el plano toxicológico para poder dar cuenta de las posibilidades extremas de lo poético. En este sentido, la rehabilitación de la alegoría para la lírica moderna se lleva a cabo en analogía con lo descripto en los paraísos artificiales, es decir, en el examen de los estados alterados de conciencia provenientes del consumo del hachís y del opio. La mediación del narcótico, en cuanto artificio aplicado a la subjetividad, es el modo en que los simples mortales pueden figurarse el equivalente del "sueño voluntario" del poeta. ${ }^{21}$ "La justificación de la alegoría por Baudelaire está pues en conexión significativa con su concepción de una teoría sobrenatural de la poesía moderna" (Jauss 2004b, pp. 149 - 150). Como en el abandono en la multitud, la embriaguez del hachís es una mística secularizada. No hay acceso al artificio sobrenatural sin el previo estallido de la identidad personal. "El punto en el que coinciden el éxtasis del hachís y la experiencia del «ensueño» poético, es el esfuerzo de dejar tras de sí la individualidad propia, para conseguir otro estado, que Baudelaire explica

21 "El ocioso se las ha ingeniado para introducir artificialmente lo sobrenatural en la vida y en su pensamiento; pero después de todo, y pese a la energía accidental de sus sensaciones, sigue siendo el mismo hombre aumentado, el mismo número elevado a una altísima potencia” Baudelaire 2010b, p. 155). 
conceptualmente como «multiplicación de la individualidad», o, metafóricamente, como creación de una «tercera persona», de un «hombre superior», etcétera" (Ibid., p. 150). El ataque de Baudelaire a la subjetividad romántica se expresa por una doble vía. Por un lado, el "sujeto lírico ya no manifiesta un mundo en tanto que expresión de un yo íntegro y único", y por el otro, en que lo sobrenatural se encuentra "fuera de cualquier simbolismo platonizante".

El paraíso artificial se muestra análogo a un producto de la manipulación artística. Por mediación del artificio Adán es restituido a su privilegio inicial. Al oponerse a lo natural, se glorifica la creación humana incluso sobre la divina. Este es el fundamento último de su herejía. La sobrenaturalaza es un estado de gracia alcanzado por la sutil intensificación de la sensibilidad, "un modo de la percepción estética realizada artificialmente". Es decir, algo cuya motivación última se encarna en la idea misma del pecado. Pues el arte, lejos de conciliar con la naturaleza, busca suplantarla, corregirla, reformarla, apuntalar la caída que abre el hueco donde todo se inicia. Bajo este registro reformista debe entenderse la asimilación de términos como "objetividad" y "panteísmo" que Baudelaire aplica a dichos estados de embriaguez trascendentes respecto de la identidad subjetiva. "Religiosa embriaguez de las grandes ciudades. Panteísmo. Yo soy todos. Todos soy yo. Torbellino" (Baudelaire 1995, p. 17). El paraíso es recobrado en las antípodas de todo impulso natural, como efecto de una borrachera cuya última finalidad se identifica con lo bello.

En Los paraísos artificiales Baudelaire describe las tres fases en las que se concreta el movimiento herético cuyo télos es el panteísmo poético. La primera, está marcada por cierta hilaridad, absurda e irresistible que se adueña de los sujetos.

Esos accesos de alegría inmotivada, de los que casi os avergonzáis, se reproducen con frecuencia y se cortan en intervalos de estupor durante los cuales intentáis en vano recogeros. Las más simples palabras, las ideas más triviales, adquieren una rara y nueva fisonomía; os asombráis, incluso, de haberlas encontrado hasta ahora tan simples. Similitud y relaciones incongruentes, imposibles de prever, interminables juegos de palabras, esbozos de comicidad, brotan consecuentemente de vuestro cerebro. El demonio os ha invadido; es inútil ir en contra de esa hilaridad, dolorosa como un cosquilleo" (Baudelaire 2010b, pp. 157 - 158). 
La hilaridad se afirma corroyendo los diques en los que se resguarda la autonomía del sujeto. Un placer jovial se regocija ante la invasión de lo inquietante. Lo nunca visto ni oído eclosiona en la novedad anónima del acontecimiento.

En cambio, la segunda fase está determinada por efectos que desquician al cuerpo. De este modo, lo preparan para una sensualidad exacerbada. El "frescor en las extremidades", la languidez de todos los miembros, dilatación de las pupilas, como sacadas por un "éxtasis implacable". "Vuestro rostro se inunda de palidez. Los labios se fruncen y van penetrando en la boca, con ese movimiento de anhelo que caracteriza la ambición de un hombre entregado a grandes proyectos, oprimido por vastos pensamientos, o cogiendo aire para tomar impulso" (Ibid., p. 162). La extrañeza ha invadido la secreta correspondencia entre el alma y el cuerpo. Como en series divergentes, ambas fluyen hacia su afuera, en la búsqueda de placeres nuevos que hallan en los intersticios de su mismo desencuentro.

Una finura exquisita, "una superior acuidad de los sentidos" se despliega en el tercer período.

El olfato, la vista, el oído, el tacto, participan, igualmente, en este progreso. Los ojos miran el infinito. El oído percibe sonidos casi inaprensibles en medio del más vasto tumulto. Es entonces cuando empiezan las alucinaciones. Lenta y sucesivamente, los objetos externos adquieren singulares apariencias, deformándose y transformándose. Llegan luego los equívocos, los errores y las transposiciones de ideas. Los sonidos se visten de colores, y los colores contienen una música (Ibid., p. 165).

El panteísmo irrumpe como una sinestesia generalizada. La alegoría despliega su vértigo de permutaciones infinitas. Las alucinaciones desatadas culminan proclamando una objetividad ganada en el declive de la permanencia individual. "A veces ocurre que la personalidad desaparece, y la objetividad, que es lo propio de los poetas panteístas, se desarrolla en vosotros de forma tan anormal, que la contemplación de los objetos externos os hace olvidar vuestra propia existencia, confundiéndoos pronto con ellos" (Ibid., p. 166). Inquietante objetividad obtenida en el artificio y en la despersonalización. Estado de ebria empatía que Benjamin asimilará como propia del flâneur, narcótica identificación con la mercancía llevada a cabo a expensas de todo rigor crítico. 
Pero el vértigo alegórico no se detiene ahí. En su vinculación no sintética de heterogeneidades llega incluso a afectar las percepciones del tiempo y del espacio. "Felizmente, esta interminable fantasía sólo ha durado un minuto, pues un intervalo de lucidez, acompañado de un gran esfuerzo, os ha permitido examinar el péndulo" (Ibid., pp. 166 - 167). La fragmentación acelerada se decanta en una sucesión rapsódica que llega a anular la mediada del tiempo.

Hace un instante, la noche; ahora el día. Y, sin embargo, había vivido mucho tiempo; joh, muchísimo tiempo!... al haber quedado anulada la noción, o mejor, la medida del tiempo, sólo podía medir la totalidad de la noche por la multitud de mis pensamientos. Por larga que, bajo este punto de vista, pudo resultarme, me parecía, sin embargo, que no había durado más de unos segundos, o incluso que no había ocupado lugar en la eternidad (Ibid., p. 171).

La inadecuación entre el tiempo sensible percibido como soporte del pensamiento y el tiempo mundano se transmuta en el ámbito de la más inquietante extrañeza. El tiempo termina por objetualizarse en la misma medida en que el espacio se desarma en infinidad temporal. Como señala Jauss, la "profundidad del espacio" deviene la alegoría de la “profundidad del tiempo" (Jauss 2004b, p. 155). La multiplicidad rapsódica y facetada de las ideas y sensaciones no cristalizan su sentido en referencia alguna a una supuesta totalidad, la alegoría en Baudelaire se distancia de la medieval en el hecho de que todo enlace deviene de un acto de invención que desconoce, en su actualización, cualquier supuesto o clave previa.

Pero este estado extático en el que la embriaguez libera a la alegoría para el juego indefinido de las sustituciones, resulta un elíxir momentáneo. En su reverso puede descubrirse "el satanismo latente en el éxtasis del hachís". Pues la desmesura del ensueño demiúrgico lleva al hombre a la pretensión de sustituir Dios. ${ }^{22}$ Por lo tanto, el panteísmo corre el riesgo de transformarse en concordia con una nueva naturaleza, susceptible de solapar bajo su presunta objetividad la supresión de la idea de pecado original. Si bien Jauss admite que la alegoría en lugar de cerrar la herida abierta entre la naturaleza y el hombre,

22 "Nadie se sentirá sorprendido de que un pensamiento final, supremo, surja del cerebro del soñador: «;He llegado a ser Dios!», ni de que un grito salvaje, ardiente, salga de su pecho con tal energía, tal poder de proyección, que si las voluntades y creencias de un hombre ebrio tuviesen una virtud efectiva, este grito derribaría a los ángeles diseminados por los caminos del cielo: «¡Soy un Dios!»” (Baudelaire 2010b, p. 185). 
proporciona la conciencia de la alienación tanto de uno como de la otra sobre el fondo del Spleen como dolor o angustia cósmica, no culmina de ser consecuente con esta posición. La alegoría no se consuma en el juego constante de las permutaciones entre interioridad y exterioridad, ni siquiera en su enrarecimiento definitivo. La alegoría es un movimiento de elevación y desplome, sólo se vuelve significante en su declinación. En la ruina, finalmente, algo se sanciona.

Por eso, luego de la orgía de percepción hipersensibilizada que lleva al hombre al despropósito idiota de adjudicarse la divinidad, como si de una parodia teológica se tratara, éste no puede sino que asumir el llamado a la limitación que decreta la aceptación de su decrepitud. En el "terrible día siguiente" los achaques del cuerpo emiten sus facturas. La fatiga y el dolor son el retorno de ese residuo natural no reparable por completo que señala cruelmente el límite al juego presuntuoso con lo interdicto. "La horrible naturaleza, despojada de su iluminación de la víspera, se parece a los melancólicos restos de una fiesta” (Baudelaire 2010b, 186). Nuevamente la melancólica claridad epigonal impregna la escena de lo bello como "su ilustre compañera". Marca esa hora decisiva, la única propicia, en que la fiesta termina y algo de la significación se precipita. Entre el hieratismo de los desperdicios finalmente el tiempo se devela como demonio voraz de una caducidad aborrecible aunque siempre definitiva.

La figura del saltimbanqui en cuanto alegoría del propio poeta ejemplifica esta atracción incontenible y melancólica hacia la decadencia. Como ha señalado Starobinski, el destino del payaso es habitar el intervalo entre el vuelo y la caída, el triunfo y la decadencia, la agilidad y la ataraxia, la gloria y la inmolación. "Baudelaire, poeta de las «dos pretensiones simultáneas», proporcionó al artista, bajo la figura del bufón y del saltimbanqui, la vocación contradictoria del vuelo y la caída, de la altura y el abismo, de la Belleza y la Mala suerte" (Starobisnki 2007, p. 67). Los Pequeños poemas en prosa nos presentan los ejemplos de esta identificación latente. En Una muerte heroica el bufón Fancioulle encarna la alegoría del artista devorado por una muerte prematura. La implicación en una conspiración fallida contra el Príncipe, modifica definitivamente la suerte del payaso. El Príncipe, que cierta sensibilidad artística le acentúa su crueldad, propone una amnistía que poco se diferencia de una "venganza refinada". En tanto que “experimento psicológico de capital importancia", éste propone el perdón a cambio de que 
Fancioulle realice su mejor actuación. La idea es "verificar hasta qué punto las habituales facultades de un artista podían ser alteradas o modificadas por la extraordinaria situación en la que se encontraba" (Baudelaire 2010a, p. 98). Fancioulle se supera a sí mismo, sobre la noche del rencor desata la aureolada iridiscencia del artificio. "Aquella noche Fancioullo fue una perfecta idealización, imposible de no suponer viva, posible, real. El bufón iba, venía, reía, lloraba, se convulsionaba, con una indestructible aureola en torno a su cabeza, aureola invisible para todos, pero visible para mí, y donde se mezclaban, en una extraña amalgama, los rayos del Arte y la gloria del Martirio" (Ibid., p. 99).

El bufón insufla lo divino y sobrenatural en la profana materia del escenario. Por un instante el paraíso parece recobrado, y el artificio sustraído a la viscosa pregnancia de la muerte. "Fancioullo me demostraba de forma perentoria, irrefutable, que la embriaguez del Arte es más apta que cualquier otra para velar los terrores del abismo; que el genio puede representar la comedia al borde de la tumba, con un gozo que le impide verla, perdido, como está, en un paraíso que excluye toda idea de tumba y de destrucción" (Idem.). Pero el artificio permanece incompleto en el mero vuelo etéreo del artista sutil. La delicuescencia de las formas propicia el momento de la suspensión, por lo demás muy frágil, tan inconsistente que es incapaz de superar la más infantil y maliciosa injuria. La insignificancia del silbido desata el desplome. "Fancioullo, sacudido, despertado en su sueño, cerró primero los ojos, casi inmediatamente, volvió a abrirlos, desmesuradamente grandes; abrió seguidamente la boca como para respirar convulsamente, se tambaleó un poco hacia delante, un poco hacia atrás, y luego cayó súbitamente muerto sobre las tablas” (Ibid., p. 100).

En El viejo saltimbanqui Baudelaire nos acerca una variación de esta identificación y de su pendiente. El narrador abreva su lirismo pesimista en un "tono de crónica parisina". Ensueño del flâneur en su éxodo pautado por los barrios de la gran metrópolis. La lujuria efervescente de un día de fiesta en la feria sirve de entorno propicio para el sabor de los contrastes. Todo es hilaridad y sensualidad multicolor. La vida afirmando su vigor, se desafía a sí misma en destreza permanente. El lívido artificio se eleva impregnado del vaporoso perfume de las frituras que figuran el incienso de la pueril ceremonia."Al final, completamente al final de la fila de barracas, como si por vergüenza él mismo se hubiese exiliado de todos estos esplendores, vi a un pobre saltimbanqui, encorvado, caduco, 
decrépito, una ruina de hombre, adosado a uno de los postes de su cabaña; una cabaña más miserable que la del salvaje más embrutecido, cuya desolación estaba todavía demasiado bien iluminada por dos cabos de vela derretidos y humeantes" (Ibid., p. 71). La visión del histrión decadente se aísla como intenso contraste. La gangrena, el recorte de lo muerto contagia, bajo el júbilo vulgar, su melancólica belleza. La impotencia de una esterilidad bizarra, como contenida al borde del precipicio de lo ridículo, resquebraja finalmente la fluorescencia del artificio. Lo bello emana como hedor de lo marchito, como abigarrada discrepancia de comicidad y luto. "El miserable no reía. No lloraba, no bailaba ni gesticulaba, no gritaba; no cantaba ninguna canción, ni de gozo ni de lamento, no imploraba. Permanecía mudo e inmóvil. Había renunciado, había abdicado. Su destino estaba cumplido" (Ibid., p. 72).

Algo de la naturaleza retorna dialécticamente para interpelar ese límite que inscribe su rechazo. El arte como herejía moderna se topa con lo imposible, y en esa misma imposibilidad, la forma se determina. Sólo en la pérdida, en ese abismo donde todo sentido claudica, en ese umbral de una materia invadida por los poderes cadavéricos, ahí y solo ahí, algo finalmente se sanciona. Perfecciona su forma como estridencia obscena de vida y muerte. "El bufón, autorretrato disfrazado del propio Baudelaire, encarna bajo una forma apenas paródica el vértigo mortal al que está expuesto el artista, no sólo porque haya osado atentar contra la persona del señor (del Padre), sino sobre todo porque sufre la falta de ser ligada a la naturaleza ilusoria del arte" (Starobinski 2007, p. 70). Fancioulle y el viejo saltimbanqui encarnan la belleza como último destello de lo que sucumbe, aunque en una leve dilación: "el uno en el paroxismo de un triunfo vano, el otro en la inmovilidad y la parálisis. Gautier era el cronista del vuelo del bufón. Baudelaire, que no ignora nada del poder del vuelo, centró su atención en la caída y el hundimiento" (Ibid., p. 76). El alegorista conoce su enfermedad, sabe que ante el abismo todo sentido se sustrae, que la alegoría es fértil en la caducidad, que algo se sanciona a costa de romper la risible cobertura con la que el sujeto se protege; finalmente, que en esta desintegración culmina por encontrase como efecto paradójico e irreversible del mismo acto en el que incesantemente se pierde.

\section{3. La alegoría}


“Las alegorías son en el reino de los pensamientos lo que las ruinas son en el reino de las cosas" (Benjamin, W. 2007, p. 396)

El recurso a lo alegórico en Baudelaire, según Jauss, se profundiza cuando el poeta se hace cargo de la temática heredada del "dolor cósmico", del ennui como "forma de la angustia cósmica", cosa "que puede comprobarse en la concreción del nuevo concepto clave de «Spleen»" (Jauss 2004b, p. 158). Si bien, a grandes rasgos y en la medida en que permanezcamos sujetos a la opresión de la media, todos estos términos, ennui, Spleen y angustia parecen ser sin más homogéneos, lícitamente intercambiables según las trasparentes permutaciones del sentido común, esta claridad, sin embargo, no cesa de opacarse una vez que problematizamos sus enlaces tratando de percibir sus posibles heterogeneidades. El ennui, aburrimiento, tedio, hastío, no parece asimilable a la angustia. Tampoco el Spleen en la formulación de Baudelaire, que en la misma línea del tedio, nos habla de esa monótona infinitud que clausura toda novedad, la extrañeza paradójica que nos interpela en la mecánica burocracia de las cosas y los días. Pues, tanto uno como el otro, aunque recojan ciertos elementos de la afectividad, no resultan fácilmente reductibles a una “psicologización”. Lejos de esta reducción, el ennui parece referirse al continuum monótono de lo que no cesa y que en Baudelaire expresa el murmullo atroz del ser. En cuanto que la angustia, por el contrario, es un infinito puntual que irrumpe en el sujeto ante la inminencia de un corte, ante la posibilidad o imposibilidad de poder afrontarlo. Si esto es así, la angustia lejos de circunscribirse al repertorio del ser, se inscribe en el registro de su contrario dialéctico, lo otro que el ser, es decir, en la nada.

Esta escisión entre el ser y la nada, expresa en último término, la alternancia que arroja como legado la poética decadentista, pues al lado de Baudelaire como poeta del ser, es Mallarmé el poeta de la nada (Ritvo 2006, p, 196). Tanto el Spleen como el ennui se confinan en Baudelaire al ámbito simultáneamente atroz y banal que abre la escena del ser. A una gratuidad estúpida que se resiste a clausurarse en la muerte. Por eso el poeta descree, con un cinismo infantil, tanto de la muerte como de la nada. "Cosa chocante, Baudelaire nunca tuvo confianza en la nada. Tiene el profundo sentimiento de que el horror de vivir no puede ser consolado por la muerte, que ella no encuentra vacío que la agote, que este horror de existir que es la existencia tiene como principal significación el sentimiento de un no se 
deja de existir, no se sale de la existencia, se existe y se existirá siempre, que es revelado en este mismo horror" (Blanchot 2007, p. 136).

Horror que acaece como reverso de esa autenticidad fugaz y esencialmente circunstancial, que destella en el esplendor trivial de lo nuevo en el que se funda -para Baudelaire- la modernidad estética. Pero en tanto que novedad que permanentemente se disipa, el deslizamiento borra cualquier registro que pueda intentar sedimentar un valor más estable de la autenticidad o de la esencia. Blanchot visibiliza este escándalo apelando a la confrontación con Heidegger.

No hay por tanto que contar con la nada para acabar, pues, cuando se ha entrado en la existencia, se ha entrado en una situación que tiene como carácter esencial que con ella no se acaba. El «ser-para-la-muerte» de Heidegger, lejos de caracterizar la situación auténtica, sólo representaría para Baudelaire una impostura más. No tenemos por delante de nosotros la muerte, sino la existencia que, por lejos que yo avance, está siempre por delante, y, por bajo que me hunda, está siempre más abajo y, por irrealmente que me afirme (por ejemplo en el arte), infesta esta realidad de una ausencia de realidad que es todavía existencia (Ibid., p. 137).

El enunciado de Blanchot resulta implacable. Describe, con realismo cruel, ese desierto de sopor en el que se funda la existencia. Como en Piranesi, el ennui es la cárcel extraviada de un hay que contiene lo infinito de la posibilidad. Ni arriba ni abajo, ni dentro ni afuera, ni ahora ni después, todo se cierra en un continuum endogámico de lo posible, una cinta de Moebius subsistiendo como autoerotismo extático. En el ser monótono, sentido y sin sentido se identifican en el punto de encuentro de la abstracta posibilidad. El vértigo del ser se muestra, entonces, como un hay en el que el sin sentido tiene sentido como mera condición de su posibilidad. De ahí que, por esta vía, nada acabe. Pues no cabe esperar corte alguno donde impera lo simplemente posible. El enunciado de Blanchot es, simultáneamente, certero y correcto. Certero porque describe con precisión milimétrica el hastío de la escena del ser en Baudelaire. Correcto porque en su precisión censura, sin embargo, un resto que la mera apelación a lo posible no puede sino que excluir. Del insomnio del ser, efectivamente, no se sale ni por arriba ni por abajo, ni por dentro ni por fuera, ni antes ni después, se sale, si es que acaso se sale, ciertamente por un corte, un 
instante elidido en el que la angustia acompaña una decisión, acto desnudo que interrumpe en lo imposible el sopor uniforme de la posibilidad.

El enunciado de Blanchot adolece del recurso a lo imposible, única instancia susceptible ciertamente de iniciar en absoluto, en tanto que suspensión del infinito intercambio numérico de lo meramente posible. Olvida, por lo tanto, la centralidad de lo dialéctico sin la cual la alegoría en Baudelaire quedaría reducida a un juego banal de melancólicas permutaciones en el marco de una escena real o irreal supeditada, en último término, a lo posible de ser. Sin embargo, tal como hemos visto, la alegoría, en cuanto que técnica al servicio de la poética de la decadencia, lleva implícita una tensión dialéctica que inevitablemente orienta su movimiento intrínseco hacia una conclusión. Quizás, en tal olvido subsista un resto de esa "usurpación" efectuada por la estética romántica que Walter Benjamin denuncia en el capítulo dedicado a la alegoría en su ensayo sobre el Trauerspiel. El despojo de la alegoría por parte del símbolo va de la mano de una borradura de lo dialéctico en provecho de la unidad de lo sensible y suprasensible que toma por modelo al símbolo teológico (Benjamin 2007, p. 376). De este modo, lo bello queda prendado del ámbito transfigurado de lo divino.

El concepto de identidad del clasicismo que busca reducir lo especulativo en provecho de una "interioridad sin contrarios" queda expuesto en su registro del símbolo. En su tratado sobre la naturaleza orgánica Goethe promueve una clasificación de los símbolos cuya operatividad queda emparentada por el repetitivo recurso a lo idéntico. ${ }^{23}$ En el

23 "Cuando queremos hablar de relaciones internas a la naturaleza, nos son necesarias varias maneras de designarlas.

1) Símbolos que son física-realmente idénticos con su objeto, tal como hemos considerado primero los fenómenos magnéticos y después los hemos adoptado como terminología en los objetos afines.

2) Símbolos que son estética-idealmente idénticos con su objeto. A esta esfera pertenecen todas las buenas semejanzas, pero hay que guardarse del ingenio (Witz), que no busca lo que es afín, sino que acerca aparentemente lo que no es afín.

3) Símbolos que expresan una referencia que no es enteramente necesaria, sino más bien subyacente a una cierta arbitrariedad, pero que, sin embargo, remite a una íntima afinidad de los fenómenos. A estos símbolos querría llamarlos mnemónicos en sentido superior, pues la memoria común se sirve de signos completamente arbitrarios.

4) Símbolos que son tomados de la matemática $y$, puesto que también en su base hay intuiciones, pueden ser idénticos a los fenómenos en el sentido más alto.” 
segundo punto de una clasificación cuaternaria concibe al símbolo como "estéticaidealmente idéntico a su objeto". Esta identidad se esclarece en la cita de Goethe que Benjamin realiza en el ensayo sobre el Trauerspiel, donde se decanta la diferencia del símbolo respecto de la alegoría. Mientras que esta última sería un "ejemplo de lo universal”, el símbolo "expresa algo particular sin pensar en lo universal”, pero agrega, “el que capta con viveza esto particular obtendrá con ello lo universal al mismo tiempo, sin darse cuenta de ello o tan sólo advirtiéndolo más tarde” (Benjamin 2007, p. 377). Esta identidad formal en la que se eclipsa toda reversión de los extremos es consustancial a una supresión de la temporalidad. A partir de la Mitología de Creuzer, Benjamin deduce negativamente una concepción de lo alegórico como subproducto de lo simbólico, que promueve paradójicamente una captación de la temporalidad inherente al dominio de la primera. El símbolo debe ser comprendido según cuatro momentos dados por "Lo momentáneo, lo total, lo insondable de su origen y lo necesario” (Ibid., p. 380). Aparición repentina, relámpago de "fecunda brevedad", se instituye en lacónica sobriedad. Una concisión que el símbolo logra a causa de un severo equilibrio intrínseco entre lo infinito y lo finito. Todo exceso se depura en provecho de la totalidad de la forma. La unidad momentánea de lo total se establece como una sutura obtenida por vía de una autolimitación de lo infinito. Cercenamiento que decanta en una plenitud en la que lo divino finalmente se humaniza.

Bajo este registro de lo simbólico, resulta comprensible la ilusoria consolación con la que el Romanticismo sostuvo su fantasma de comunidad entre el hombre y la totalidad orgánica de la naturaleza. El símbolo es siempre momento necesario de una totalidad, instantaneidad sin interrupción y por lo tanto, convincente fantasía de un retorno sin resto ni opacidad. Por el contrario, en lo alegórico el instante deviene rapsódico, una serie fragmentaria que matiza un impulso progresivo. La temporalidad se derrama impelida por su misma esencia dialéctica, por su íntima y específica violencia que no puede sino que declinar hacia la pérdida. El punto decisivo entre símbolo y alegoría gravita, entonces, en derredor de la categoría del tiempo. "Mientras que en el símbolo, con la transfiguración de la caducidad, el rostro transfigurado de la naturaleza se revela fugazmente a la luz de la redención, en la alegoría la facies hippocratica de la historia se ofrece a los ojos del 
espectador como paisaje primordial petrificado. En todo lo que desde el principio tiene de intempestivo, doloroso y fallido, la historia se plasma sobre un rostro; o mejor, en una calavera" (Ibid., p. 383). En la alegoría la soteriología de la transfiguración se desvanece en favor de lo caduco. La ilusión de una salvación sin restos se derrumba ante la visión de la muerte que se anuncia inminente en un rostro. Instante petrificado, eternamente suspendido, comprimido, siempre a punto de advenir y ya de algún modo advenido. Advenido como tormento que se concreta en su misma falla, como presencia de la muerte en tanto imposible que abre el campo de lo posible, y que en esta abigarrada obscenidad condensa la máxima intensidad de la eminencia y de la caída.

Por eso, en la poética decadentista de Baudelaire, la belleza resulta inviable si no se encuentra violentamente mancillada. Arrojada salvajemente al pretil de lo corrupto. Pues lo alegórico fermenta en una esfera de decadencia incontenible. En este contexto, el declive reviste a la degradación de un perfil de derroche. Un lujo que el poeta sustrae de la prostitución de los seres que reptan en una naturaleza continuamente devaluada. Como en lo faisandé, la alegoría se reconoce como un más allá de la belleza. En ese choque sensual, aunque aporético, que emana de los "limoneros" junto con los “cadáveres". En la sutil amalgama de un perfume levemente dulce y apacible pero que se encuentra rápidamente invadido por el hedor nauseabundo que despide la putrefacción. Ahí donde el pecado extirpa la vida de la naturaleza y del hombre, aplastando a la criatura humana contra la muerte, el poeta encuentra la falta de objeto que es el lugar donde todo inicia. De tal decrepitud, el poeta sustrae la suntuosidad de su palabra. "A mayor significado, mayor sujeción a la muerte, pues sin duda es la muerte la que excava más profundamente la dentada línea de demarcación entre la phýsis y el significado. Pero si la naturaleza siempre ha estado sujeta a la muerte, viene a ser igualmente de siempre alegórica” (Ibid., p. 383).

Entre 1852 y 1870 se realizan las transformaciones urbanísticas a gran escala planeadas por el barón Haussmann. París se somete a la dinámica acelerada de un cambio que conjuga en un mismo acto la coagulación de destrucción y creación. Por un intervalo

24 "La naturaleza continuó así siendo la gran maestra para los poetas del período. Pero no se les hizo manifiesta en el brotar de la yema y de la flor, sino en lo marchito y decadente de sus criaturas. La naturaleza aparece a esos poetas como una eterna caducidad, sólo en la cual la mirada saturnina que es la propia de aquellas generaciones reconocía como tal la historia. (...) La quintaesencia de las cosas que decaen constituye el extremo opuesto al concepto de naturaleza transfigurada elaborada por el temprano Renacimiento" (Ibid., p. 398). 
acaecido en el tiempo, la ciudad se precipita en un abismo alegórico en el que sucumbe en suspenso la textura heterogénea de su pasado medieval y el sulfuroso ensueño de su planeado porvenir. A principios del siglo XX son aún visibles los restos extraviados de este proceso devastador. Eugène Atget es el retratista tardío de este cataclismo. Retratista involuntario, sin pretensiones artísticas, registra como un archivista, sus "documentos para artistas", vistas agónicas de una ciudad desaparecida. En sus fotogramas se conjugan las callejuelas pululantes entre pasajes y patios internos que como fantasmales escaparates se clausuran en ruinosos condominios. La atmósfera matinal irrealiza las escenas que se saturan en neblina mortecina, tanto más inquietantes cuanto que permanecen absolutamente desérticas. Como si la materia fosilizada fuera la única realidad susceptible de congeniar con la muerte. Como en los grabados de Charles Méryon el estrépito invade ante la inquietud de lo inhumano. Pero además de sus nostálgicas vistas, Atget retrata a los personajes cuyos oficios constituyen los últimos estertores de un pasado ya anémico. Fantasmas ingrávidos se resisten al olvido prestándose a la artificial fijación en una imagen en la que se decreta, paradójicamente, lo irreversible de su evaporación.

Desde 1850 Charles Marville, contemporáneo de Baudelaire, se consagra como el fotógrafo oficial del Estado cuya misión será registrar el plan de trasformaciones urbanísticas diseñadas por Haussmann. Si Atget es el fotógrafo de lo superviviente. Marville lo es del interludio, es decir, del entreacto en el que colisiona, como mutación en proceso, el mundo que perece y aquel que no cesa de nacer. Las imágenes de Malville documentan un pasado primordial, cuasi épico, de aquellas barriadas hoscas aún intactas a la amplitud de las altercaciones. Su crónica visual da cuenta de la violencia dramática que conlleva el cambio. Algo de la naturaleza caída retorna como semblante de lo muerto en la fisonomía de la ciudad. En sus fotos asistimos a una devastación en la que el único testigo es el objetivo de la lente. Como si lo vivo sólo pudiese ser observado a través del tamiz mecánico de lo muerto. El desmoronamiento asombroso, escombros sobre escombros, descompleta la asfixiante acumulación del primer plano con la vista adyacente de un espacio abierto, ya modernizado. En Marville también abunda la desaparición de lo humano. La desolación es interrumpida en esos escasos momentos en los que el observador es llamado a contemplar la fantasmagoría de la escala inhumana del desastre. El resplandor insiste en la superficie de las calles vacías, resquebraja su presencia fascinante en próxima 
desintegración. Si ante la mirada de Baudelaire todo París devenía alegoría, bajo la lente de Marville todo París deviene un decorado. Decorado en el que se despliega el drama universal que confronta la tierra con el cielo. Drama sólo interrumpido por la sombra fantasmal e imponente de la cúpula del panteón.

\section{Conclusión}

En la primera parte del texto hemos intentado circunscribir tres modos de configuración estética del vínculo posible entre el tiempo y la belleza. Pues, lo moderno estético irrumpe en el marco de una añeja querella como movimiento de autocomprensión que busca legitimarse en su escisión respecto de los modelos heredados de la tradición. Esto no implica que necesariamente esta legitimación deba comprenderse como oposición a la precisión formal del ideal clásico de belleza. Como hemos intentado demostrar, la naciente interpelación por la esencia histórica del arte en Winckelmann, emerge como un intento de constituirse a partir de la fallida sutura de esa herida temporal que, sin embargo, la posibilita. En la restauración neoclásica, el tiempo se somete al ideal de belleza eterna sobre la base del principio de imitación como figura del retorno. Pero todo retorno es un nuevo inicio, por lo tanto, la imitación crea a su pesar eso mismo que supuestamente descubre. La imitación reproduce un esquema de repetición diferencial que a la vez que constata la desaparición real del objeto, cicatriza dicha falta por la vía del Ideal. En este sentido, ella se nos ha descubierto como una poética del duelo. Finalmente, el prestigio de la belleza ideal se fundamenta en la desmesura de su ausencia categórica. Desde esa ausencia deviene norma y deber para toda actualidad, por lo tanto, censura de la novedad bajo la dictadura del Ideal.

En su retorno a Winckelmann, Schlegel pretende una confluencia sintética de la antinomia entre lo antiguo y lo moderno. Pero dicha convergencia culmina resultando también fallida. Pues, en esa divergencia, no sólo encuentra la esencia de lo moderno, sino que incluso la repite en acto. La subjetividad es el hiato que se incrusta como una cuña entre la esencia antigua y la moderna. En este sentido, lo interesante es la marca del arte moderno en su figuración romántica. Lejos de todo duelo, no cesa de profanar lo clásico en su mismo acercamiento. En el hundimiento de la forma clásica, lo interesante deviene 
modelo para lo interesante. El tiempo y la belleza se vivencian como momentos de dicha subjetividad. La dispersión y el desborde formal sólo logran una coagulan provisional, en la viscosa anomalía de lo interesante.

Finalmente, en Baudelaire se reconfigura la relación entre el tiempo y la belleza. No sólo se acentúa el descrédito por las formas ideales de belleza, sino que además, se agrega a esta última, la descomposición de la subjetividad interesante. La poética de Baudelaire se posiciona en guerra con los postulados románticos. La Modernidad estética se concibe como una entrega sin reservas al balbuceo circunstancial e infinito de la novedad. Pero lo nuevo será percibido contra la trama contradictoria y angustiante de aquello que declina. Es, por lo tanto, el impalpable centelleo que cristaliza en la superficie de un torbellino de fuerzas encontradas. La novedad se encuentra en ese afuera que se conforma como entrecruzamiento de lo moderno en tanto que aspiración naciente, $\mathrm{y}$, de lo decadente como impulso fascinado por la destrucción.

En la segunda parte del texto, hemos pretendido develar la manera en que la poética de Baudelaire se muestra en disrupción respeto del Romanticismo. Esta ruptura se lleva a cabo fundamentalmente en la reactualización de la alegoría contra toda usurpación, más o menos solapada, del concepto romántico de símbolo. En este sentido, la singularidad del ligamen entre temporalidad y belleza debía presentarse bajo la marca del retorno de lo alegórico. Este retorno no sólo se lleva a cabo contra el símbolo, sino que incluso debe ejercerse contra la naturaleza y la subjetividad. Contra la naturaleza orgánica pensada ahora desde la condición del pecado original, y por lo tanto, degradada y caduca. Solamente a partir de esta caída puede comprenderse la elevación maníaca que representa la herejía moderna entendida como la doctrina del arte en cuanto artificio. Contra la subjetividad, pues con el pecado, además de la naturaleza se desploma la naturaleza humana. De manera que, en el artefacto, aquello que sirve de corrección es el signo mismo de una subjetividad que se eclipsa. Es decir, el acceso al artificio sobrenatural no es posible sin el previo estallido de la identidad personal. La alegoría irrumpe en el abismo que precipita a la naturaleza y a la criatura humana hacia la muerte. En este sentido, la naturaleza azotada por la muerte, como fosforescencia de su podredumbre, ha sido desde siempre intensamente alegórica. 


\section{Bibliografía}

Barthes, R. (2003). El teatro de Baudelaire. En Ensayos críticos. Buenos Aires, Argentina: Seix Barral.

- (1996). El pintor de la vida moderna. En Salones y otros escritos sobre arte. Madrid, España: Visor.

— (1995). Mi corazón al desnudo y otros papeles íntimos. Madrid, España: Visor.

- (2010a). Pequeños poemas en prosa. Madrid, España: Cátedra.

- (2011). El cisne. En Las Flores del mal. Buenos Aires, Argentina: Colihue.

— (2010b). Los paraísos artificiales. Madrid, España. Cátedra.

- (2005). Correspondencia General. Buenos Aires, argentina: Paradiso.

- (2001). De la esencia de la risa y en general de lo cómico en las artes plásticas. Madrid, España: Visor.

Benjamin, W. (2007). El origen del “Trauerspiel” alemán, en Obras libro1 / vol. 1. Madrid, España: Abada.

Blanchot, M. (2007). El fracaso de Baudelaire. En La parte del fuego. Madrid, España: Arena.

Bourget(2008). Charles Baudelaire. En Baudelaire y otros estudios críticos. Córdoba, Argentina: Ediciones del Copista.

Didi-Huberman, G. (2013). La imagen superviviente. Madrid, España: Abada.

Eliot, T. S. (2015). Baudelaire. En La aventura sin fin. Barcelona, España: Debolsillo.

Flaubert, G. (2003). Cartas a Louise Colet. Madrid, España: Siruela.

Gay(2007). Modernidad: La atracción de la herejía de Baudelaire a Beckett. Barcelona, España: Paidós.

Goethe, J. W. von (2013). Teoría de la naturaleza. Madrid, España: Tecnos. 
Habermas, J. (2012). El discurso filosófico de la modernidad. Buenos Aires, Argentina: Katz.

Huysmans, J. K. (2012). A contrapelo. Madrid, España: Cátedra.

Jauss (2004a). El arte como anti-naturaleza. El cambio estético después de 1789. En Las transformaciones de lo moderno: Estudio sobre las etapas de la modernidad estética. Madrid, España: Antonio Machado Libros.

- (2004b) El recurso de Baudelaire a la alegoría. En Las transformaciones de lo moderno. Estudio sobre las etapas de la modernidad estética: Estudio sobre la modernidad estética. Madrid, España: Antonio Machado.

Kayser, W. (2010). Lo grotesco. Su realización en literatura y pintura. Madrid, España: Antonio Machado.

Münster, R. (1995). El derecho a la libertad. Historia, revolución y estética objetiva en la obra temprana de Friedrich Schlegel. Introducción a Schlegel F. Sobre el estudio de la poesía griega. Madrid, España: Akal.

Nietzsche (2003). Sobre la utilidad y el perjuicio de la historia para la vida. Madrid, España: Biblioteca Nueva.

Praz, M. (1999). La carne, la muerte y el diablo en la literatura romántica. Barcelona, España: Acantilado.

Ritvo, J. B. (2006). Decadentismo y melancolía. Córdoba, Argentina: Alción.

Rousseau, J. J. (2008). Las ensoñaciones del paseante solitario. Madrid, España: Alianza.

Schlegel (1995a). Sobre el estudio de la poesía griega. Madrid, España: Akal.

- (1995b). Fragmentos del Lyceum (1797). En Poesía y Filosofía. Madrid, España: Alianza.

- (2009). Fragmentos del Athenaeum (1798). En Fragmentos. Barcelona, España: Marbot. Starobinski, J. (2007). Retrato del artista como saltimbanqui. Madrid, España: Abada. Valéry(2010). Situación de Baudelaire. En De Poe a Mallarmé: ensayos de poética y estética. Buenos Aires, Argentina: Cuenco de plata. 
Cuadernos Filosóficos. Segunda Época, XII, 2015

Winckelmann, J. (2008). Reflexiones sobre la imitación de las obras griegas en la pintura y la escultura. Madrid, España: Fondo de Cultura Económica.

— (1985). Historia del arte en la antigüedad. Madrid, España: Ediciones Orbis. 